\title{
WHY DO MARRIED MEN CLAIM SOCIAL SECURITY BENEFITS SO EARLY? IGNORANCE OR CADDISHNESS?
}

\author{
Steven A. Sass, Wei Sun, and Anthony Webb* \\ CRR WP 2007-17 \\ Released: October 2007 \\ Draft Submitted: October 2007 \\ Center for Retirement Research at Boston College \\ Hovey House \\ 140 Commonwealth Avenue \\ Chestnut Hill, MA 02467 \\ Tel: 617-552-1762 Fax: 617-552-0191 \\ http://www.bc.edu/crr
}

* Steven Sass is the Associate Director for Research at the Center for Retirement Research at Boston College (CRR). Wei Sun is a graduate research assistant at the CRR. Anthony Webb is a research economist at the CRR. The research reported herein was performed pursuant to a grant from the U.S. Social Security Administration (SSA) funded as part of the Retirement Research Consortium. The opinions and conclusions expressed are solely those of the authors and should not be construed as representing the opinions or policy of SSA, any agency of the Federal Government, or Boston College.

(C) 2007, by Steven Sass, Wei Sun, and Anthony Webb. All rights reserved. Short sections of text, not to exceed two paragraphs, may be quoted without explicit permission provided that full credit, including $\mathbb{C}$ notice, is given to the source. 


\title{
About the Center for Retirement Research
}

The Center for Retirement Research at Boston College, part of a consortium that includes parallel centers at the University of Michigan and the National Bureau of Economic Research, was established in 1998 through a grant from the Social Security Administration. The Center's mission is to produce first-class research and forge a strong link between the academic community and decision makers in the public and private sectors around an issue of critical importance to the nation's future. To achieve this mission, the Center sponsors a wide variety of research projects, transmits new findings to a broad audience, trains new scholars, and broadens access to valuable data sources.

\author{
Center for Retirement Research at Boston College \\ Hovey House \\ 140 Commonwealth Avenue \\ Chestnut Hill, MA 02467 \\ phone: 617-552-1762 fax: 617-552-0191 \\ e-mail: crr@bc.edu \\ www.bc.edu/crr
}

\author{
Affiliated Institutions: \\ American Enterprise Institute \\ The Brookings Institution \\ Center for Strategic and International Studies \\ Massachusetts Institute of Technology \\ Syracuse University \\ Urban Institute
}




\begin{abstract}
Most married men claim Social Security benefits at age 62 or 63, well short of both Social Security's Full Retirement Age and the age that maximizes the household's expected present value of benefits (EPVB). This results in a loss of less than 4 percent in household EPBV. But essentially the entire loss is borne by the survivor benefit, falls nearly 20 percent. As many elderly widows have very low incomes, early claiming by married men is a major social problem.
\end{abstract}

Regression results found no association between early claiming and caddishness or the ability of husbands to make claiming decisions independently. The one statistically significant finding is the association of college education and later claiming, which cautiously take to indicate greater financial awareness. This suggests that an effective educational campaign might be able to raise the claiming ages of married men and improve widows' retirement income security. But financial education has not been especially effective in changing behavior. Policymakers should thus consider other initiatives to assure a survivor benefit greater than that produced by an age 62 or 63 husbands' claiming age. Such initiatives include raising the Earliest Eligibility Age, requiring spousal consent for claiming prior to the Full Retirement Age, and preserving the survivor benefit at its Full Retirement Age value and allowing the higher-earning spouse to access only a portion of his (or her) Primary Insured Amount prior to the Full Retirement Age. 


\section{Introduction}

Most married men claim Social Security benefits at age 62 or 63, well short of Social Security’s Full Retirement Age. That married men claim so early is somewhat surprising. The “money's worth" value of lifetime benefits accruing to the married couple-the couple's expected lifetime benefits discounted to the present at a 3 percent real rate of interest-is almost always greater if the man claimed benefits several years later. The gains from delay would be even greater if we include the value of the insurance Social Security provides. That married men claim so early is also problematic. It results in much lower benefits for their surviving spouse and the low incomes of elderly widows is a major inadequacy of our retirement income system.

Part I of this paper will outline the Social Security benefit design and the incentives in the design for married men to postpone claiming. Part II reviews the literature on claiming and its effect on the expected present value of household Social Security benefits. Part III presents new estimates of the claim ages that maximize the expected present value of household Social Security benefits for a sample of households in the initial Health and Retirement Study cohort (the cohort where the household head was born between 1931 and 1941), and losses those households suffer if the husband and wife claim as soon as they became eligible. Part IV describes a regression examining the effect of ignorance and caddishness on early claiming by married men. Part V presents the results of that regression. Part VI discusses the policy implications.

\section{The Social Security Benefit Design and the Incentive for Married Men to Delay Claiming}

Workers can claim Social Security benefits as early as age 62-the Earliest Eligibility Age (EEA) — or as late as age 70. The later a worker claims, the shorter the period of benefit receipt but the higher the monthly benefit. At a 3 percent real interest rate, the increase in monthly benefits from age 62 to Social Security’s Full Retirement Age (FRA) is approximately actuarially fair for single workers with average life expectancy. During 
this period, the expected present value of benefits (EPVB) is much the same no matter when the worker claims. The increase in monthly benefits from the FRA to age 70 has been less than actuarially fair. The increase, called the "Delayed Retirement Credit" (DRC), has been rising and will be actuarially fair for workers born after 1942. For workers in older cohorts, however, their EPVB declined if they claimed past the FRA.

The EPVB for married couples is much more complicated due to special spousal and survivor benefits the program provides. While both husband and wife are alive, each is entitled to the greater of their own earned monthly benefit or-if both husband and wife have claimed - a monthly benefit based on their spouse's Primary Insurance Amount (PIA), or monthly benefit if claimed at the FRA. The guaranteed monthly amount is onehalf of the spouse's PIA if claimed at the claimant's FRA; if claimed prior to the FRA, the guaranteed monthly amount is reduced at a steeper rate than the reduction applied to the worker's own earned benefit; if claimed after the FRA, the monthly amount is not increased. Social Security also provides a guaranteed survivor benefit upon the death of a spouse. The survivor is entitled to the greater of his or her own earned benefit or their spouse's earned benefit, subject to a relatively modest reduction if claimed before the FRA. Spousal and survivor benefits are almost invariably received by married women, as they generally have lower lifetime earnings than their husbands (necessary for the receipt of either benefit) and because they generally survive their husbands (necessary for the receipt of a survivor benefit) as they are generally younger than their husbands and have greater life expectancy. For more details on the Social Security benefit design, see Appendix 1.

The notion that the present value of Social Security benefits for individual workers is much the same no matter when a worker claims from age 62 to the FRA is valid for workers with average life expectancy. Not all workers, however, have average life expectancy. Workers in good health can generally expect to live longer than those in poor health. Workers who are well-off tend to live longer than those who are poor. Of particular significance to our analysis, life expectancy at age 62 is 19 years for the average man and 23 years for the average woman. Because of their greater life 
expectancy, women who delay claiming can expect to receive an increase in monthly benefits over a greater stretch of time than men. Claiming later thus has a more positive effect on the EPVB of single women than of single men. As seen in Figure 1, the EPVB for single women born in 1937 and 62 in 1999 — the average birth-year and age for the Health and Retirement Study individuals who will be the focus of this paper-rises for each year she postpones claiming up to the FRA while our estimate of the EPVB for single men born that year is much the same at all claim ages between 62 and the FRA. The increase in the EPVB for single women is nevertheless relatively small, rising less than 3 percent if she delays claiming from age 62 to her FRA of 65 . Due to the less-thanactuarially fair DRC for beneficiaries born in 1937, the EPVB for both single men and single women decline if they claim after the FRA.

For married couples, the focus of our study, Social Security's spousal and survivor benefits significantly complicate the effect of claiming ages on the household's EPVB. Many married women receive spousal benefits and the great majority receives survivor benefits. In the typical case, where the wife is younger than her husband and entitled to a survivor benefit upon his death, the EPVB she receives while her husband is alivewhether her own earned benefit or a spousal benefit—is generally greatest if she claims at 62. If she delays, she will receive the increased monthly benefit, whether her own earned benefit or a spousal benefit, only until her husband dies and she begins to collect a higher survivor benefit. She cannot expect to receive that increased monthly benefit long enough to make up for the monthly benefits foregone while she delayed claiming. The length of time a wife can expect to receive a survivor benefit, by contrast, is unaffected by the age at which she or her husband claims. The monthly survivor benefit she receives is her husband's actual benefit, not his PIA, and her husband's monthly benefit rises 7 to 8 percent for each year he postpones claiming up to the FRA. Since the rise in the monthly survivor benefit is not offset by any reduction in the duration of benefit receipt, a husband's later claiming age has a large positive effect on the EPVB of his wife's survivor benefit. 
The EPVB valuations of benefits discussed above-the expected present values of benefits over a household’s expected remaining life_-are simple “money’s worth” calculations. They do not include various characteristics of Social Security benefits that alter their value to participants. The most important characteristic that raises the value of Social Security benefits above the simple money's worth calculation is the insurance, or retirement income security, they provide. Social Security benefits guarantee beneficiaries a precisely defined real income for as long as they live. There is an extensive literature, for example Mitchell, Poterba, Warshawsky and Brown (1999) and Brown and Poterba (2000) showing that the value of an annuity substantially exceeds its money's worth by reason of the longevity insurance it provides. Social Security benefits are also insured against financial risks that affect most other income sources, such as inflation, credit, real return, and reinvestment risk. Treasury Inflation Protected Securities (TIPS) of appropriate durations can provide such insurance, but they currently have somewhat lower yields than the 3 percent used in our EPVB calculations and are rarely found in household portfolios. Workers who postpone claiming acquire additional amounts of longevity insurance on terms that are actuarially fair, even assuming a better-than-market 3 percent real rate of return. They also shift benefit receipt to older ages, when they run a significant risk of having much less income and wealth. While households can also use the capital markets to reallocate consumption across time, many do not, as evidenced by the heavy dependence of many widows on Social Security benefits. This reallocation of income to older ages is especially valuable for married women as they are likely to significantly outlive their husbands, experience large income declines after their husbands die, and as widows become heavily dependent on Social Security survivor benefits (McGarry and Schoeni, 2005).

Not all characteristics of Social Security benefits boost their value above the EPVB calculations and thereby boost the incentive to postpone claiming. Social Security benefits are illiquid, cannot be bequeathed, and cannot be borrowed against. While these characteristics make Social Security benefits less attractive, they are unlikely to explain why the great majority of households claim early. A household can satisfy its bequest motive by setting aside the amount it wishes to bequeath and few households are likely to 
have a bequest motive that they cannot satisfy out of non-Social Security wealth. In terms of the timing of consumption, delay shifts benefit receipt away from the near-term, when both spouses are living, and increases benefits when only the wife is likely to be alive. Some households might prefer higher consumption when both are alive and relatively young, preferring to consume market-supplied services such as movies or restaurants together, in their 60s, rather than alone at the end of their lives. But households that wish to consume their wealth while both are alive can generally do that much more effectively by increasing the rate of decumulation of financial wealth. Liquidity is a more plausible explanation why households might claim early. Upon retirement, households must choose between claiming and tapping their financial wealth. Those fearing health and long-term care expenses might prefer to leave their financial wealth intact. While this is a plausible explanation of early claiming, it does not appear sufficient. Even households with large amounts of financial wealth often claim early.

Households will differ in the value they place on the insurance, illiquidity, and nonbequeathability of Social Security wealth and on benefits received at different stages of life. These values are unlikely to be well-defined, constant over time, or easily known by either the household or researcher. Including these attributes in estimates of the value of Social Security benefits thus would require the use of many arbitrary assumptions. So we follow previous literature by using simple money's worth expected present values as our yardstick for measuring the effect of claiming ages on the value of a married household's benefits.

\section{Previous Literature on the Effect of Claim Ages on Social Security Wealth}

Two studies, Coile, Diamond, Gruber, and Jousten (2001) and Munnell and Soto (2005) have estimated the effect of claiming ages on the value of a married household's lifetime Social Security benefits. Like our study, both used the present value of expected benefits as its measure of Social Security wealth at different claiming ages. Like our study, they also used a 3 percent real discount rate in their baseline estimates. 
The first, Coile, Diamond, Gruber, and Jousten (2001), calculated the value of Social Security wealth at different husband's claiming ages for one-earner couples with population mortality. They assume that the wife claims as soon as possible, which maximizes the expected value of benefits in most, but not all, cases. In their base case, which assumed that the husband was born in 1930 and the wife in 1932, so both have a FRA of 65, the present discounted value of the household's lifetime benefits was greatest if the husband claimed at age 65 assuming the wife claimed at 63, when her husband claimed. If the husband claimed as early as possible, at age 62, so that the wife claimed at the same age, the household lost $\$ 6,270$, or 3 percent, relative to claiming at 65 and 63 .

The second study, Munnell and Soto (2005), calculated the combinations of claim ages that maximize the EPVB of household benefits at a 3 percent real rate of interest where both spouses have a FRA of 66 and population mortality for the cohort born in 1948. They show how the claim ages that maximized the value of the household's Social Security wealth depended on the age difference between the spouses and the relative sizes of their PIAs. The value of lifetime benefits was generally greatest when the husband claimed between age 66 and 69. This is later than for the older cohort studied in Coile et al. (2001), reflecting the increase in life expectancy and in a more generous DRC. The claiming age of the wife that maximized the household's Social Security wealth depended on the relative size of the spouses' PIAs. It was 62, as soon as possible, if her PIA was at least 40 percent of her husband's, making her ineligible for a spousal benefit. If her PIA was very small, the household EPVB was greatest if she claimed at the same time as her husband. ${ }^{1}$

While both studies find that the present value of a household's Social Security benefits is generally greatest if the husband claims at 65 or later, the great majority of married men claim at 62 or soon thereafter. This increases the value of benefits received over their own lifetime, as men have shorter life expectancy than women and Social Security

\footnotetext{
${ }^{1}$ If the wife with a very low PIA claimed at 62, she would be eligible for a spousal benefit when her husband claimed. But 62 would remain her claiming age, so her spousal benefit would be substantially reduced. The optimal claiming ages of wives who have a more substantial earned benefit but are also eligible for a spousal benefit is more complex and depends on the relative ages of the husband and wife.
} 
benefits are actuarially raised, if they delay, based on unisex life tables. But claiming later substantially reduces the benefits their surviving spouses can expect to receive. Unless households offset this shift in Social Security benefits to younger ages by accumulating additional financial wealth, the husbands' early claiming would be a significant contributor to the problem of widow poverty and near-poverty. Gruber and Orszag (1999) report that the average Social Security benefit in 1998 of widows aged 90 and above, whose husbands had claimed at or above the FRA, was 19 percent above the projected 1998 Federal Poverty Line. Widows whose husbands had claimed sooner, by contrast, had average benefits 1 percent below the poverty line. Widows rarely have much financial wealth (Zick and Holden, 2000). This suggests that early claiming was not a decision on the order of asset draw-down-Social Security first and financial assets second-but if anything a decision on the timing of household consumption-more early in retirement when both husband and wife were alive and less later on, when only the wife was likely to be living.

Why married men claim benefits early is not well understood. There have been numerous studies attempting to explain why men (and women) retire when they do. But retiring and claiming are not the same thing. Retirement, in the sense of earning less than the maximum allowed by the Social Security Retirement Earnings Test (RET), is a necessary but not a sufficient condition for receiving full benefit. While workers generally retire and claim at about the same time, they do not have to claim until age 70, irrespective of when they retire. Most households have sufficient financial wealth to allow the husband to retire but postpone claiming. And as we have seen, married men would generally increase the present value of household benefits if they claimed at a later age. $^{2}$

Only two previous studies have analyzed the Social Security claiming decision independent of the retirement decision. The first, Coile, et al. (2001), analyzed the claiming behavior of single and married men who had retired before age 62. They were

\footnotetext{
${ }^{2}$ Analyses of the retirement decision often assume that households claim Social Security immediately on retirement, resulting in mis-specified estimates of the Social Security incentive to retire.
} 
thus unable to claim benefits when they retired. Their age of claiming was thus a financial decision, separate from their decision to retire. The study, which used administrative data from the Social Security Administration's New Beneficiary Data System (NBDS) for the period from mid-1980 to mid-1981, found that most men in their sample claimed as soon as they became eligible or soon thereafter. But a substantial minority did delay. The study found a positive relationship between the decision to delay and some indicators of its effect on the household's Social Security wealth, measured as lifetime EPBV. Households that would lose or see little or no increase in Social Security wealth if they delayed-single men, those with shorter life expectancies, and married men with older wives_claimed relatively early; those with larger gains-married men with younger wives and men with longer life expectancies - tended to delay. But the average delay was relatively short and appeared to leave significant amounts of Social Security wealth "on the table."

The study also identified household wealth as influencing the age of claiming, with both rich and poor households claiming relatively early. The authors suggest this reflects impatience and/or liquidity constraints at low wealth levels, as these households have no other source of income and are unable to borrow against the gain in Social Security wealth that delay would produce. They suggest that early claiming at high wealth levels reflects a strong bequest motive and a decision to draw down non-bequeathable Social Security wealth and preserve financial wealth, which is bequeathable. Even after controlling for this inverse "U”-shaped relationship between delay and household wealth, however, significant amounts of Social Security wealth appear to be left “on the table.”

The second study, Hurd, Smith, and Zissimopoulos (2004), analyze claiming behavior in the 1992 to 1998 waves of the Health and Retirement Study (HRS) using the participants' self-reported claiming ages. They find little to explain the age of claiming except differences in subjective mortality beliefs. People with very pessimistic subjective mortality beliefs claimed earlier. But the effects were not large. Like Coile, et al. (2001), they also found that most households leave money on the table, claiming much earlier than the ages that would maximize the household's Social Security wealth. 


\section{New Estimates of Claim Ages That Maximize Social Security Wealth}

In this section we present calculations of our measure of Social Security wealth for a sample of married households at different combinations of claim ages, the combination that maximize their Social Security wealth, and of the amount of wealth, if any, each leaves “on the table.” These calculations use data from the Health and Retirement Study (HRS), a nationally representative panel of individuals born between 1931 and 1941 and their spouses, matched to newly available administrative data on their earnings histories and Social Security claiming ages. ${ }^{3}$ Following Coile, et al. (2001), we limit this sample to households in which the husband had retired before age 62. The age of claiming can thus be viewed as a purely financial decision, separate from the husband's labor supply decision.

Our calculations extend previous research in two ways. First, by looking at actual rather than prototypical households, we capture the effects of the joint distribution of the various determinants of Social Security EPVB — for example any correlation between the relative PIAs of husband and wife and their age difference, which both affect EPVBthat researchers using prototypical models either address with assumptions or ignore. Second, we calculate household EPVB for every possible combination of the husband's and wife's claim ages. This approach gives the maximum EPVB, the EPVB based on the ages at which husband and wife actually claimed, and the amount (if any) each household left “on the table.” We can then estimate the effect of various household characteristics on the propensity to do so.

In addition to HRS data, the following analysis uses newly available Social Security earnings and claim records with data up to 31 December 2003 available to researchers on a restricted basis. Of the 7,793 individuals who consented to the HRS obtaining their

\footnotetext{
${ }^{3}$ Coile, , et al.(2001) supplemented their econometric analysis of the NBDS data with an analysis of HRS data extending to 31 December 1991 to verify that the pattern of claim ages had not changed up to that date. But as only a small proportion of the HRS sample had turned 62 by that date, their findings were based primarily on analyses of the NBDS data from the early 1980s. As the HRS panel only commenced in 1992, it was also not possible to obtain wealth and other data for these individuals at the time they turned 62 .
} 
records, 1,396 are married men born between 1930 and 1941—men who turned 62 on or after the first wave interview in 1992 and before 2003, the last year in which earnings records are available, who were married both at the interview before they turned 62 and the interview after they claimed benefits. ${ }^{4}$ Of the 1,396 observations, 5 were dropped because these men married different wives between age 62 and their claim ages, ${ }^{5}$ leaving 1,391; 151 were dropped because they had claimed disability benefits, ${ }^{6}$ leaving 1,240 ; and 116 were dropped because they had non-FICA income for at least five consecutive years, ${ }^{7}$ leaving 1,124; 23 were dropped because they had worked less than 40 quarters before they turned $62,{ }^{8}$ leaving 1,101; and 30 were dropped because they had very low earnings and can be considered to never have worked, leaving 1,071. Following the method developed by Coile, et al. (2001) to isolate claiming from retirement, 729 married men were dropped because they retired after age 62, leaving 342 observations. (We define a man as retired if his earnings in the year he turned 62 were less than the Social Security retirement earning test (RET) threshold or if he had no earnings from the start of the quarter in which his $62^{\text {nd }}$ birthday fell until the end of the year and earned less than the RET threshold the following year.) $)^{9}$ Another 2 were dropped due to a lack of wealth data when they turn 62, leaving 340 observations. Finally, 153 were dropped because their spouses’ earnings information was unavailable, leaving the final sample of 187. The Social Security benefit calculations in this section use the sample of 187 households. The regression analysis that follows uses the larger sample of 340 households, with the wives' unknown AIMEs estimated as equal to the average ratio of wife's to husband's AIME in the sample of 187 households (See Table 1).

\footnotetext{
${ }^{4}$ Because our research interest is the claiming decisions for married men which are made at 62 , we need information when the husbands turn 62. As the HRS started in 1992, we have to drop the men who turn 62 before the first wave interview. In addition, because the earnings records end in 2003, we have to drop the men who turn 62 after 2003 too.

${ }^{5}$ These men are likely to have financial and marital situations quite different from men living with a longterm spouse.

${ }^{6}$ Disability benefit represents a separate pathway to retirement that is subject to its own particular rules.

${ }^{7}$ Individuals who have both FICA and non-FICA income are subject to special rules designed to prevent excessive benefits that would otherwise result from the non-linear relationship between average lifetime earnings and Social Security benefits payable.

${ }^{8}$ People must have 40 or more quarters of covered earnings to be eligible for Social Security benefits.

${ }^{9}$ The Social Security earnings records show the total amount of income earned during each calendar year and the number of quarters' covered earnings in each year.
} 
Figure 2 shows the distribution of claim ages of the men in the 187-person sample. These claiming ages, based on newly available linked administrative records, are more accurate and often quite different from the self-reported claiming ages found in the HRS. ${ }^{10}$ While the overall pattern of early claiming is quite similar to that found in the self-reported data, the discrepancies demonstrated the importance of using administrative data in analyses of claiming behavior. As seen in Figure 2, over 90 percent of married men in this sample claim at age 62. Those who delay, however, often postpone claiming for quite some time.

Our results for the claiming ages that maximize the present value of household Social Security benefits are similar to those found by Coile, et al. (2001) and Munnell and Soto (2005). ${ }^{11}$ This is seen in Figure 3, which shows the mean household Social Security EPVB for households in our sample at all 81 combinations of claiming ages assuming population mortality and a three percent rate of time preference. ${ }^{12}$ Households, on average, maximize household Social Security EPVB when the husband claims at 66 and the wife at 62 .

The maximizing ages for individual households in our sample show little variance for women but significant variance for men. This is seen in Figure 4, which shows the combination of claiming ages that maximize the EPVB for each household in our sample. While 84 percent of households maximize when the woman claims at 62, only 17 percent maximize when the husband claims at 66.

\footnotetext{
10 The records form part of the HRS restricted data made available to qualifying researchers under conditions put in place to safeguard confidentiality. Not all men in the sample had claimed by December 31, 2003, the last wave available at the time of our study. In constructing Figure 2, we estimate the percent who claim at any given age based on the behavior of men in the sample who had attained that age by December 31, 2003. Thus our estimate of the percent of men who claim at 62 is the percent who claimed at 62 among those who were 62 by December 31, 2003; our estimate of the percent who claim by 63 is the percent who claimed by 63 among those who were 63 by December 31, 2003, and so on.

${ }^{11}$ Coile, et al. (2001) did not address the claiming ages of the wife and Munnell and Soto (2005) used a younger sample with greater longevity, a higher FRA, and a more generous DRC.

${ }_{12}$ Mortality is average mortality for people in the relevant birth year derived from Social Security cohort mortality tables. The median values for household Social Security EPVB at the various combinations of claim ages are quite similar to the mean values shown in Figure 3.
} 
Most of the husbands in our sample claim much earlier than the age that maximizes the household's EPVB. This is seen in Figure 5, which compares actual claiming ages with the age that maximizes the household's Social Security wealth. The vertical distance above or below the 45 degree line represents the number of years that the husband claims later or sooner than the maximizing age. The size of the circle indicates the number of observations at each combination of maximizing and actual claiming ages. ${ }^{13}$

While most married men claim several years earlier than the maximizing age, this tendency generally results in rather small losses of household Social Security wealth. The average loss resulting from both husband and wife claiming as soon as possible at $62,{ }^{14}$ rather than delaying to the combination of ages that maximize the household's EPVB, is just \$14,135 (in 2006 dollars), 4 percent of the maximum value. So at least in money's worth terms, households are not leaving enormous amounts of wealth on the table. These relatively small losses, similar to those reported by Coile, et al. (2001) and Munnell and Soto (2006), should not be surprising given the flatness of the surface of Figure 3. There is, nevertheless, reasonable heterogeneity in the losses incurred by the individual households. Figure 6 presents these losses in dollar and in percentage terms.

The generally small losses in the present value of total household benefits, however, hide substantial survivor benefit losses. While the average household would lose just 4 percent in total Social Security wealth if both husband and wife claimed at 62, the expected present value of the survivor benefit would fall 19 percent, from $\$ 70,906$ to $\$ 57,251$. As the duration of benefit receipt is essentially unaffected by the couple’s claiming ages, the 19 percent reduction in the value of the average survivor benefit largely reflects a reduction in the average survivor benefit from $\$ 1,558$ to $\$ 1,162$ per month (or from $\$ 18,696$ to $\$ 13,944$ per annum), a 25 percent reduction. The reduction in

\footnotetext{
${ }^{13}$ As we include only those men who earned less than the RET threshold, men that delay claiming beyond the maximizing age are not doing so as a result of the earnings test.

${ }^{14}$ We use the EPVB of benefits when both husband and wife claim at 62 because 1) it is the apparent option for couples who retired prior to becoming eligible to claim benefits at age 62 and the benchmark against which they must evaluate the benefits of delay; 2) it is close to the actual claim ages of most households in our sample; and 3) it is close to the minimum EPVB, so the shortfall against the couple's maximum EPVB is a reasonable approximation of the couple's maximum possible loss from not claiming at the maximizing ages.
} 
the monthly survivor benefit is essentially equivalent to the reduction in the husband's earned benefit resulting from his claiming, on average, 4 years prior to the maximizing age. $^{15}$ For the distribution of survivor benefit losses in our sample, see Figure 7.

As seen in Figure 8, the annual benefits survivors in our sample will receive are quite low and would clearly create hardship if they had little or no other income. The annual benefit fell below the poverty line in 13 percent of households and below the "nearpoverty" line in 23 percent of households. ${ }^{16}$ For households with these low levels of Social Security benefits, and with surviving spouses typically holding few financial assets and receiving little or no defined benefit pension income, the money's worth yardstick likely understates the reduction in the value due to early claiming.

Figure 9 decomposes the total loss of benefit resulting from both spouses claiming at age 62, averaged over our sample, into the change in the EPVB payable over the husband's expected lifetime, and the change in that payable to the surviving spouse. The $\$ 13,655$ decline in the expected present value of the survivor benefit should both husband and wife claim at 62 accounts for nearly the entire \$14,351 reduction in household Social Security EPVB, from $\$ 366,677$ to $\$ 352,316$. Claiming as soon as possible reduces the expected present value of benefits payable while the husband is alive by $\$ 695$-less than .25 percent. Had the couple postponed claiming to their maximizing ages, the value (and level) of the survivor benefit would be nearly 25 percent greater while the EPVB while the husband is alive would be essentially unchanged.

\footnotetext{
${ }^{15}$ The survivor benefit of a widow whose husband had not claimed and dies before reaching the FRA is based on her husband's PIA. The survivor benefit would be his PIA if claimed on or after the widow's FRA and reduced if claimed prior to the FRA. As wives are generally younger than their husbands, the survivor benefit when the husband dies prior to the FRA is generally less than his PIA.

If the husband dies prior to the FRA and his maximizing age is greater than the FRA, his wife's survivor benefit, based on his PIA, would be less than had he survived and claimed at the maximizing age. If the husband's maximizing age is less than the FRA, an early claimant gives up the possibility that he dies before claiming and the survivor benefit basis is "topped up" to his PIA — an amount greater than had he survived and claimed at the maximizing age. Our calculations make the simplifying assumptions that all husbands claim before they die (so there is no "top-up" in the basis of the survivor benefit to the husband's PIA) and that the wives of men who die before the FRA and have not claimed claim on attaining their FRA (so there is no reduction in the survivor benefit due to early claiming).

${ }^{16}$ Where the level of the survivor benefit in our sample is uncertain because the wife has not attained the FRA, we assume she is at least as old as the FRA when she claims the survivor benefit. The benefits shown in Figure 8 are greater than the cash payments survivors will actually receive as they are not reduced by Medicare Part B premiums, which are deducted before the checks are sent out.
} 


\section{What Might Explain Early Claiming?}

The general pattern of early claiming by married men 1) leaves Social Security wealth “on the table;” 2) sharply reduces benefit receipt at a time when only the wife is likely to be alive; and 3) unless additional financial wealth is accumulated to compensate, significantly increases the risk that the wife will face hardship should she become a widow. We now consider the effect of two factors that could lead to such early claiming-ignorance and household decision-making. The hypotheses we will test is that married men are more likely to claim early if they are 1) financially unsophisticated, 2) are either cads or have the power to make major household decisions independently.

To test for the effect of ignorance and household decision-making, we control for factors identified in earlier studies to influencing claiming behavior- expected longevity and household wealth. We also control for the household's financial planning horizon. Although differing from the household's unobserved rate of time preference, the household's financial planning horizon has been shown to influence savings behavior in a manner similar to the predicted influence of the rate of time-preference (Lusardi and Mitchell, 2006). ${ }^{17}$

Following Coile, et al. (2001), we also limited our sample to households that retired prior to becoming eligible to claim Social Security benefits. Many workers clearly seem to conflate the retirement and claiming decisions, even though the first involves a trade-off between labor and leisure while the second is purely financial. The retirement decision is quite complicated and involves a great many factors that would interfere with our attempt to identify the effect of caddishness and ignorance on claiming behavior. Limiting our study to household that have already retired before they are able to claim provides a

\footnotetext{
${ }^{17}$ Gustman and Steinmeier (2002) suggests that a bimodal distribution of rates of time preference, with impatient households claiming early and the more patient choosing to delay, contributes to the observed pattern in claiming behavior.
} 
cleaner perspective on the influence of these factors on a key household financial decision. $^{18}$

\section{Expected longevity}

We control for subjective mortality beliefs, more specifically, respondents' estimates of their probability of attaining age 75 , which have been shown to affect claiming and to vary appropriately with known risk factors and determinants of mortality.

\section{Financial wealth}

We control for financial wealth, an indicator of households' ability to postpone claiming.

\section{Time preference}

Our analysis will also control for financial planning horizon, both as a proxy for the household's unobserved rate of time preference, which has been posited as a possible explanation of claiming behavior, and also because of its potential direct effect. As the age of claiming has a significant effect on the timing of benefit receipt, the rate at which the household discounts future benefits could have a dramatic effect on a household's maximizing claim ages. This is illustrated in Figure 10, which show the distribution of maximizing ages based on population mortality and interest rates of zero and five percent. In our basic model, using a three percent interest rate, households generally maximize when the wife claims at 62 and the husband claims between 65 and 69. At a zero percent interest rate, however, the maximizing age is 65 for many wives and 70 for many men. At a five percent interest rate, by contrast, wives should almost invariably claim at age 62 and men between the ages of 62 and 65. (Appendix 2 gives the HRS financial planning horizon questions and other HRS questions used in the analysis.)

\section{Financial awareness}

Ignorance of the benefits of delay could clearly reduce the propensity to postpone claiming. Studies of financial awareness among workers at the cusp of retirement are

\footnotetext{
${ }^{18}$ It is not possible to identify the age of retirement with sufficient accuracy to permit an extension of the model to include the duration of delay in claiming among those who retire after age 62.
} 
hardly encouraging, and thus could underlie the widespread practice of claiming early. ${ }^{19}$ The HRS includes a financial planning module that measures a household's financial awareness. But few respondents participate in this module. Instead we use three financial/numerical literacy questions asked of all non-proxy participants that provide a less comprehensive measure of financial awareness (see Appendix 2). We also control for educational attainment, which is correlated with financial literacy (Lusardi and Mitchell, 2006) and a reduction in the general propensity to overvalue lump sums relative to income flows (Warner and Pleeter, 2001) — an important consideration in the decision to delay and give up money in-hand today in order to increase income flows tomorrow.

\section{Household Decision-Making}

Caddishness could lead husbands to claim early. The distribution of benefit receipt certainly seems caddishly indifferent to the well-being of a surviving wife. But testing whether caddishness is the cause of this distribution is not so simple. The HRS does not ask men how much they care about their wife's well-being. However, it does ask "Some couples like to spend their free time doing things together, while others like to do different things in their free time. What about you and your (husband/wife/partner)? (Do you like to spend free time doing things together; some together, some different; or different/ separate things?” While the response to this question is not a direct measure of caddishness, we conjecture that responses may be correlated with caddishness.

The husband, as the covered worker, has the legal authority to claim his own earned Social Security benefits as soon as he chooses. But whether he actually has the power within the household to make such decisions could be another matter. The HRS asks: "When it comes to making major family decisions, who has the final say - you or your (husband/ wife/ partner)? By 'major family decisions' we mean things like when to retire, where to live, or how much money to spend on a major purchase.” Individuals could answer that they themselves had the final say, that their spouses did, or that the division of responsibility was “about equal.” Friedberg and Webb (2006) show that

\footnotetext{
${ }^{19}$ Lusardi (2006), for example, finds significant levels of financial illiteracy among individuals approaching retirement.
} 
decision-making power, as measured by the above variable, depends on plausible variables within the household and also influences important household outcomes. ${ }^{20} \mathrm{We}$ thus test whether husbands empowered to make an important financial decision without reference to his spouse are more likely to claim early.

The most interesting complication in assessing the effect of household decision-making on claiming behavior is that the leading theories of such decision-making assume that caddishness should have no effect. Traditional "common preferences" models assume both husband and wife seek to maximize a joint family utility function, with neither caddishly pursuing a separate agenda. Of course, the husband and wife may agree that their joint preference is for more consumption early in retirement and less later. But our money's worth calculations indicate that this preference should only affect claiming behavior to the extent that the household is unable to achieve its desired age-profile of consumption by adjusting the rate at which it decumulates financial wealth.

"Cooperative bargaining” models assume both husband and wife are self-interested cads; but they shrewdly cooperate to maximize the "household surplus," with caddishness and decision-making power affecting only the division of that surplus. As in "common preferences" models, the husband and wife will generally claim Social Security benefits at the household's "optimal” combination of ages. The husband might nonetheless claim early if the wife is unable to offer an appropriate monetary or non-monetary compensation for delayed claiming.

The comments in the above paragraphs assume perfect information. But it is possible that: 1) both husband and wife are unaware of the implications of early claiming and are guided by social convention; or 2) only the wife is unaware, so her caddish husband has an incentive to avoid negotiations and thereby keep her in the dark. (See Appendix 3 for a discussion of household bargaining models.)

\footnotetext{
${ }^{20}$ The responses are nevertheless noisy measures of decision-making power because 1 ) the answers are discrete reports of a continuous variable, and 2) there is less than complete agreement between the spouses on the balance of power. This raises a number of econometric issues that are discussed in detail in Friedberg and Webb (2006).
} 


\section{Descriptive Statistics and Regression Results}

Our study seeks to understand claiming as a financial decision, independent of the household's labor-leisure retirement decision. As such, we focused on 340 households that had retired by age 62. We also restricted our sample to households for which we have administrative data on claiming ages and benefit amounts, as such data are critical to our analysis and the self-reported data in the HRS are often quite different (and presumably incorrect). In 153 households, we estimate the wife's AIME as the average proportion of the husband's AIME in the 187 households where the earnings histories of both spouses are available. Like Coile, et al. (2001), who used a data set from the early 1980s, we found that the great majority of households retiring prior to age 62 claimed benefits within a year of becoming eligible. In only 24 households, 7 percent of our sample of 340 households, did the husband postpone claiming for at least one year. Given the small size of our sample and the limited variance in our dependent variablethe probability that a household will postpone claiming for at least one year-we cannot expect statistically compelling results.

Table 2 provides descriptive statistics comparing the 24 households that delayed to the 316 where the husband claimed at age 62. The two groups are compared in terms of wealth, expected longevity, and financial planning horizon (our control variables), financial literacy, educational attainment (which is likely correlated with the household's unobserved rate of time preference and imperfectly measured level of financial literacy), caddishness, the decision-making power of the husband, and the combination of caddishness plus decision-making power. Tables 3 and 4 report probit marginal effects where the dependent variable is the husband postponing claiming until at least age 63. Table 3 uses financial literacy to measure financial awareness and Table 4 uses educational attainment.

In both the descriptive statistics reported in Table 2 and the regression results reported in Tables 3 and 4, show only one statistically significant characteristic differentiating late from early claimers - a college-education. We thus discuss the descriptive statistics and 
regression results together. We first discuss the results for our control variables and then for financial awareness and caddishness.

\section{Household Wealth.}

In contrast to Coile, et al. (2001), we find no statistically significant relationship between the age of claiming and household wealth. ${ }^{21}$ The 24 households in which the husband delayed claiming for at least a year are not noticeably different, in terms of financial wealth, than those in which the husband claimed at age 62 .

\section{Expected Longevity}

In contrast to Coile, et al. (2001) and Hurd, et al. (2004), we find no statistically significant relationship between the age of claiming and the respondent's expected longevity, possibly reflecting our sample size. We note, however, that the effect of expected longevity on the age of claiming was generally small and only marginally statistically significant in the previous studies.

\section{Time Preference.}

A high rate of time preference could clearly induce households to claim early. However, we find no statistically significant relationship between the age of claiming and the household’s financial planning horizon, a related concept.

\section{Household Decision-Making}

Early claiming by married men produces a caddish outcome, significantly raising the risk that their wives will face hardship as a widow. But while the distribution of benefit receipt can reasonably be viewed as caddish, we find no evidence to attribute early claiming to decisions made by caddish husbands. In both the descriptive statistics and the regression results, the 24 husbands that postponed claiming are actually more caddish

\footnotetext{
${ }^{21}$ This finding could be due to the fact that we measure household wealth differently. We use non-housing financial wealth while Coile, et al. (2001) also include housing wealth in their measure. Neither study included defined benefit pension claims in their household wealth estimates.
} 
and more likely to have decision-making power than the 316 husbands who claimed at 62 . In no case, however, are the relationships statistically significant. ${ }^{22}$

If we assume that the current pattern of claiming is sub-optimal, in the sense that households are leaving value on the table, we have no evidence the caddish or empowered husbands are the cause. This might be because early claiming, on average, has essentially no effect on the Social Security EPVB while the husband is alive. Without any real financial incentive to claim early, a husband who is aware of the financial implications of claiming early would need to be worse than caddish to exposed his wife to a substantial 19 percent reduction, on average, in the value and level of her survivor benefit - $\mathrm{a}$ benefit received when other sources of income tend to dry up. And rather than caddishness, let alone hostility, the great majority of husbands in our sample found spending time with their wives “extremely” or "very” pleasurable and generally preferred spending time with their spouse to spending time by themselves.

\section{Financial Awareness}

If the current pattern of claiming is sub-optimal and caddish husbands are not to blame, ignorance of the financial implications could well be the culprit. We find no statistically significant relationship between the age of claiming and our measure of financial literacy. But we do find a strong relationship between the age of claiming and educational attainment. Education is associated with characteristics, other than financial awareness, that could influence claiming behavior. These include income and wealth, longevity, time preference ${ }^{23}$, and perhaps caddishness and decision-making power. As the regression reported in Table 4 includes variables reasonably associated with these other characteristics, we take the strong relationship between education and delayed claiming to indicate the effect of greater financial awareness.

\footnotetext{
${ }^{22}$ We would like to test whether the combination of caddish and decision-making power is what matters. We might expect empowered cads to claim early, but not cads without power nor empowered but noncaddish husbands. But our small sample size essentially made that impossible. Empowered cads accounted for 4 percent of the husbands that postponed and the same 4 percent of the husbands that claimed at 62 . But 4 percent of the 24 husbands that postponed is just 1 husband.

${ }^{23}$ Warner and Pleeter (2001) show that education affects time preference. Educational attainment is also likely correlated with cognitive ability. However, we found no statistically significant relationship between the age of claiming and cognitive ability, using various cognitive ability measures in the HRS.
} 
The "non-cooperative bargaining” literature emphasizes the importance of social convention in influencing outcomes. It seems reasonable that households aware that social convention produces sub-optimal outcomes would be the ones most likely to alter their behavior. While results derived from our small sample must be viewed as extremely tentative, the notion that social convention is the primary explanation of suboptimal early claiming, and financial awareness the primary corrective, seem reasonable and consistent with the broader household bargaining literature.

\section{Policy Implications}

Early claiming by married men reduces the expected present value of the household's Social Security benefits, but not by large amounts. Despite the small reductions in pension wealth, the age at which men claim benefits has important implications for retirement income security. First, many households claim as soon as they retire. Early claiming is therefore part of the larger problem of early retirement that reduces the period over which households accumulate wealth and increases the period over which they decumulate that wealth. Second, by substantially reducing the benefits payable to surviving widows, it increases their risk of falling into poverty. This latter question has received inadequate attention and is the focus of our comments in the following paragraphs.

In order to fashion a policy response, our analysis attempted to gauge the influence of caddishness and financial awareness on the claiming behavior of married men. It could not associate early claiming with caddishness. But it did find a strong relationship between educational attainment and the decision to postpone claiming. Education may affect claiming behavior through a number of channels. Although we concede this is entirely conjecture, it is possible that social convention plays a large part in the age at which households claim benefit, and that the better educated are better able to buck convention. 
Early claiming has been a social convention for a quarter of a century. This trend was largely the result of the decline in the average age of retirement and the strong connection between retiring and claiming when employer defined benefit pensions were the primary source of retirement income, other than Social Security, for most retirees. Employer pensions were annuities designed to provide a supplementary stream of income, atop the retiree's Social Security benefits. Few retirees had the financial assets needed to top up their monthly pensions and postpone claiming for any length of time. So most had to claim when they retired.

For married couples with sufficient assets to postpone claiming, they could improve their financial position by bucking convention, drawing down those assets, and postponing claiming their Social Security benefits. Most invest a significant share of their retirement assets in bonds or bank deposits with a real yield lower than that implicit in Social Security's actuarial adjustment for later claiming. Drawing such assets down to postpone claiming in effect exchanges the household's bonds and bank deposits for more of an asset - as reflected in the increased present value of expected benefits - that also provides valuable insurance against significant financial and mortality risks. Common-sense, as well as the results of our study, supports the notion that the awareness of such positive effects would incline a household to pursue such a strategy. ${ }^{24}$

With the shift from employer defined benefit pensions to 401(k)s, many more retirees will be able to control the draw-down of their private retirement resources. They will be able to access their public and private retirement wealth sequentially rather than simultaneously, separate retiring and claiming, and improve their retirement income security. To the extent that awareness of the improvement in retirement income security induces married men to postpone claiming, public policy would benefit from an educational campaign that raises such awareness.

\footnotetext{
${ }^{24}$ The gains outlined are for household with average life expectancy that hold bonds or bank deposits as a retirement income asset as opposed to an asset they intend to bequeath or hold as a precautionary asset. In addition to the additional insurance households would gain if they postpone claiming, they might also be able to reduce their tax burden (Mahaney and Carlson, 2006)
} 
It is not clear that the government could mount a campaign that succeeds in making the general population genuinely aware of the beneficial effects of delaying the age at which most married men claim. The evidence on the effectiveness of workplace financial education is mixed at best (Lusardi, 2005). A household that delays claiming Social Security can be regarded as exchanging a lump sum, the money it would have received had it not delayed, in return for a lifetime income. Warner and Pleeter (2001) show that individuals tend to overvalue lump sums relative to income flows. Social Security statements already inform individuals of benefits payable at age 62, the Full Retirement Age, and age 70. It would be useful if the statement also indicated the impact of delay on the amount of the survivor benefit. A more robust educational effort would likely be needed to explain how delay increases the household's retirement income security — not just due to the general increase in the “money's worth” present value of expected benefits but, more importantly, by the insurance Social Security provides in the presence of critical financial and mortality risks. ${ }^{25}$

Given the public interest in assuring retirement income security and the threat posed by early claiming to the retirement income security of widows, policymakers should also consider other responses.

One response would be to increase Social Security’s Earliest Eligibility Age in line with the rise in the FRA. This would prevent the household's minimum benefit, both when the husband and wife or when just a survivor is living, from falling due to the rise in the FRA. As has been extensively discussed, raising the EEA would harm those who rationally wish to retire at age 62 but lack the financial resources to postpone claiming. It would be especially burdensome for a subset of this group - those unable to work due to adverse health or labor market conditions_-and would likely require an expansion of alternative public sources of support. Raising the EEA would also be unfair to

\footnotetext{
${ }^{25}$ It seems critical that the age-of-claiming decision not be framed as the age to which one must live in order to break even. Framing the issue this way, as is done by the Social Security Administration's on-line calculator, invites participants to view the claiming decision as a risky gamble that they lose if they die too soon and win if they live to a ripe old age rather than as valuable insurance against outliving their wealth. Aside from providing a distorted albeit easily grasped version of a money's worth present value calculation, it misdirects participants away from Social Security's primary value, as the source of retirement income security, and directs them to base their claiming decision on their odds of living to the "break-even" age.
} 
individuals and groups with poor life expectancy. Raising (or maintaining) the EEA would thus involve a trade-off between the welfare of those who would lose and those who need help to “do the right thing” (Cutler, Liebman, and Smyth, 2007).

Another response is to require spousal consent for benefits claimed before the FRA. ${ }^{26}$ The retirement income security of the lower-earning spouse (nearly always the wife) significantly depends on the claiming decision of the higher-earning spouse who, for whatever reason, might wish to claim early. Requiring spousal consent for early claiming would formally recognize that both spouses have a legitimate interest in the benefit and claiming decision. It would also have several behavioral effects that should improve retirement income security. First, it would tend to establish the FRA as the default age for claiming, as participants would then not need to jump through a hoop to receive their benefits. $^{27}$ Defaults have been shown to have a powerful effect on worker behavior in 401(k)s, a somewhat analogous setting; ${ }^{28}$ and social convention, which has a similar influence on behavior, is likely an important determinant of claiming behavior. Second, requiring spousal consent for early claiming can be expected to provoke discussion within the household as to the costs, benefits, and consequences of claiming at various ages. The outcome of such discussions is likely to depend on the information available to the household and the way that information is framed. Third, requiring spousal consent for early claiming will alter the balance of power within the household. We found no evidence in our limited sample that caddish husbands with decision-making power claimed earlier than caddish husbands without such power. This is the result one expects

\footnotetext{
${ }^{26}$ A similar rule requires participants in defined benefit pension plans to obtain spousal consent before taking a single life, as opposed to joint life annuity. This requirement is estimated to increase the take up of joint life annuities by as much as 25 percent (Holden and Nicholson, 1998; Saku, 2001).

${ }^{27}$ At present, Social Security's default claiming age could be said to be 70 , as the checks will start arriving at 70 unless the beneficiary claims at some other age. From the perspective of social convention, however, 62 or 63 has become the default claiming age as most participants see their friends and co-workers claiming at those ages.

${ }^{28}$ The reasons why defaults have a powerful effect on behavior in 401(k) plans is not clear. One possibility is that workers recognize that participating in the plan is the "right thing to do" but, absent the default, would not enroll due to the perceived difficulty of choosing a contribution rate and investment allocation. To the extent that this is the reason why defaults are so effective in $401(\mathrm{k}) \mathrm{s}$, they would not have a similar effect in altering Social Security claiming ages if households think that the husband claiming at 62 is a mistake but the "right thing to do"—or at least "right enough" to jump through the hoops the default creates in order to get their benefits early.
} 
from households engaged in "cooperative bargaining." ${ }^{29}$ It is nevertheless plausible that increasing the wife's power over the claiming decision would have some effect, especially as requiring spousal consent for early claiming would likely also raise the default or conventional claiming age and increase her awareness of the financial implications of her husband claiming early. Finally, requiring spousal consent for early claiming might dominate an increase in the EEA if it generally raised claim ages to 64 or higher while allowing those for whom claiming at 62 or 63 is optimal to do so.

A third response would be to assure survivors a benefit at least equal to his or her spouse's PIA—its value if the spouse had claimed Social Security benefits at the FRA. This could be accomplished by dividing the higher-earning spouse's benefit (for simplicity, assume the husband's benefit) into two portions. One portion would be reserved for the survivor and the other to be accessed while the husband is alive. In our sample of households, the survivor benefit generally accounted for 15 to 20 percent of the husband's benefit if claimed at the FRA. Benefits received during his lifetime accounted for the remaining 80 to 85 percent. To avoid undue administrative and retirement planning complications, preserving the survivor benefit at its FRA level would likely require the higher earning spouse's benefit to be divided in a uniform way. If the higher earner could access 80 percent, a husband who claimed at 62, with an FRA of 66, would get an "early retirement" benefit equal to 60 percent of his PIA, not 75 percent of his PIA; if the higher-earner could access 85 percent, he would get an "early retirement" benefit equal to 64 percent of his PIA.

Raising the ages at which married men claim would produce significant gains in retirement income security. However, it would also raise Social Security's benefit obligations at a time when the program faces serious financing shortfalls. Comparing the EPV of household benefits at the maximum claim ages with the EPV of benefits when both husband and wife claim at 62, as shown in Figure 9, the magnitude of this increase

\footnotetext{
${ }^{29}$ In current cooperative bargaining models, the wife's bargaining power depends on her "threat point," or utility in the event of divorce. Her utility in the event of divorce would likely remain unchanged unless she retained her ability, in the event of a divorce, to prevent her husband from claiming prior to the FRA. If her bargaining power does increase, she would be expected to get a larger share of the unchanged household surplus created by the current claiming ages.
} 
in benefit obligations should be less than 4 percent. Later claiming ages can be expected to result in later retirement ages. So Social Security will likely recoup some of the additional cost through additional OASDI and Medicare payroll tax revenues, that do not produce an equivalent increase in benefit obligations. The federal government will also see an increase in revenues, primarily from the income tax.

Gauging the overall fiscal impact of raising the claiming ages of married men is beyond the scope of this paper. So is an evaluation of the ways in which claiming ages could be raised. This paper has shown that raising the claiming ages of married men would have a significant effect on retirement income security with a major improvement in the retirement income security of widows, a serious social problem. The analysis of the claiming behavior of married men who retired prior to becoming eligible for Social Security finds that educational attainment, taken as an indicator of financial awareness, is a major factor in explaining their claiming behavior. Although the prevalence of early claiming by married men produces a caddish outcome, the analysis does not find caddishness to be the cause. Although the results of the analysis must be viewed as quite tentative, they suggest that an educational campaign that succeeds in raising financial awareness could increase claiming ages. The difficulty in mounting a campaign that influences behavior, and the significant social interest in assuring retirement income security, suggests that policy-makers also consider changes in the Social Security program that would raise claiming ages. These include raising the EEA, requiring spousal consent for early claiming, and basing early retirement benefits on a portion of the worker's PIA in order to preserve the survivor benefit at its FRA level. 
Appendix 1. The Social Security system

\section{Institutional features}

Social Security retired worker benefits earned by reason of one's own contributions can be claimed at any age from 62 to 70, subject to an earnings test that has become less stringent over time. The calculation of benefits involves four steps. First, a worker's previous earnings are restated in terms of today's wages by indexing past earnings to wage growth. Second, earnings for the highest 35 years are averaged and divided by twelve to calculate Average Indexed Monthly Earnings (AIME). Third, the Social Security benefit formula is applied to AIME to produce the Primary Insurance Amount (PIA), the benefit payable at the Full Retirement Age (FRA). Finally, benefits are adjusted to produce permanently lower or higher benefits for those who claim before or after the FRA. Benefits are reduced by 5/9 of one percent for each month they are received prior to the FRA up to 36 months, and 5/12 of one percent thereafter. The delayed retirement credit has increased substantially over the years, from $1 / 4$ of one percent for those born between 1917 and 1924 to 2/3 of one percent for those born after 1943.

On average, women live longer than men, and therefore would have a stronger incentive to delay claiming were it not for the existence of spousal and survivor benefits. These benefits are payable when they exceed the benefit payable by reason of the woman's own earnings record. The spousal benefit equals 50 percent of the husband's PIA when claimed at the wife's FRA. She can claim it as early as age 62, provided her husband has already claimed, subject to a reduction of 25/36 of one percent for each month they are received prior to the FRA up to 36 months, and 5/12 of one percent thereafter. There is no delayed retirement credit. The survivor benefit equals 100 percent of the husband's benefit, which can be greater or less than his PIA, depending on the age that he first claimed benefit. It is subject to a reduction of 0.475 percent for each month it is received prior to the wife's FRA for women born in 1939 or earlier, decreasing to 0.339 percent a month for those born in 1962 or later. It is not increased if the husband's death occurs after the wife's FRA. Married men are also entitled to these benefits, but they rarely have much if any value because married men usually have larger PIAs then their wives, and usually pre-decease them.

How the above features affect the return to delayed claiming 
The present value of a single individual's expected Social Security benefits equals:

$$
\sum_{t=62}^{t=120} P_{t} * B^{t-62} * \Pi_{i}^{t}
$$

the sum of the benefits payable from age 62 onwards, discounted by a rate of time preference, and multiplied by annual survival probabilities.

In most cases, a married woman has a lower PIA than that of her husband, and depending on their respective ages of claiming, will claim survivor benefit on his death. Although the wife's return to delayed claiming is approximately actuarially fair over her life expectancy, her time frame for evaluating the return to delay is the life expectancy of her husband. Mathematically, the present value of expected her benefit equals:

$$
\sum_{t=62}^{t=120} P_{t} * B^{t-62} * \Pi_{w}^{t} * \Pi_{h}^{t}
$$

The sum of the benefits payable from age 62 onwards, discounted by a rate of time preference, and multiplied by the probabilities by the probabilities that both wife and husband are alive in each period. The final term in the equation is lower for more distant periods, with the result that benefits payable in those periods are given relatively less weight in the present value calculations, reducing the return to delay. This is particularly true when the husband is older than the wife, or is in poor health.

Although the husband's return to delayed claiming is also approximately actuarially fair over his lifetime, delay also increases the survivor benefit. The value of the survivor benefit depends on the probability that the wife will survive her husband, and on the amount by which the survivor benefit exceeds the greater of the wife's retired worker and spousal benefit. 
Appendix 2. Questions in the HRS used in the regression.

\section{Planning Horizon}

In deciding how much of their (family) income to spend or save, people are likely to think about different financial planning periods. In planning your (family's) saving and spending, which of the time periods listed in the booklet is most important to you [and your (husband/wife/ partner)]?

1. Next few months

2. Next year

3. Next few years

4. Next 5-10 years

5. Longer than 10 years

\section{Financial awareness}

Next I would like to ask you some questions which assess how people use numbers in everyday life.

1. If the chance of getting a disease is 10 percent, how many people out of 1,000 would be expected to get the disease?

2. If 5 people all have the winning numbers in the lottery and the prize is two million dollars, how much will each of them get?

3. Let's say you have $\$ 200$ in a savings account. The account earns ten percent interest per year. How much would you have in the account at the end of two years?

\section{Cadishness}

Generally speaking, would you say that the time you spend together with your (husband/wife/partner) is

1. Extremely enjoyable

2. Very enjoyable

3. Somewhat enjoyable

4. Not too enjoyable

Some couples like to spend their free time doing things together, while others like to do different things in their free time. What about you and your (husband/wife/partner)? (Do you like to spend free time doing things

1. Together.

2. Some together, some different (volunteered)

3. Different/separate things

\section{Bargaining Power}

When it comes to making major family decisions, who has the final say -- you or your (husband/wife/partner)?

[DEFINITION: By "major family decisions" we mean things like when to retire, where to live, or how much money to spend on a major purchase.]

1. Respondent

2. About equal

3. Husband/wife/partner 
Appendix 3: A brief review of household bargaining models

Early models of household behavior, for example Samuelson (1956), ignored distribution within the family. These models assume that family members pool income, have “common preferences,” and make decisions that maximize a family utility function based on those preferences. The distribution of income and consumption between husband and wife only affects household decisions to the extent that it changes the household's opportunity set.

The “common preferences” model has been rejected as empirically flawed (and naïve!) in numerous papers, ${ }^{30}$ and has been largely superseded by cooperative bargaining models. Canonical models of cooperative bargaining by McElroy and Horney (1981) and Manser and Brown (1981) assume that spouses work together to maximize household "surplus" - the gain from marriage as opposed to living as two single people-and then bargain over the division of that surplus. ${ }^{31}$ In the Nash bargaining game, the outcome maximizes the Nash social welfare function $N=\left(U^{i}-R^{i}\right) *\left(U^{o}-R^{o}\right)$, which is the product of each spouse's surplus from marriage, where $U^{j}$ and $R^{j}$ are spouse $j$ 's marriage and reservation utility, or threat point. In the divorce threat model that is commonly considered, the threat point is utility from divorce. ${ }^{32}$ For example, suppose that $U^{j}=Y^{j}$, $j$ 's share of exogenous household income $Y=Y^{i}+Y^{o}$. Then $N=\left(Y-Y^{i}-R^{o}\right) *\left(Y^{i}-R^{i}\right)$, and the equilibrium is $Y^{i}=\frac{Y+R^{i}-R^{o}}{2}$, subject to $Y^{j} \geq R^{j}$. A general result of cooperative bargaining is that a spouse's allocation of income increases with their own and decreases with the other's threat points.

In terms of our study, the canonical "cooperative bargaining” model thus assumes that caddishness and decision-making power will have no effect claiming ages. The model essentially assumes that both spouses are cads. More to the point, it assumes that the

\footnotetext{
${ }^{30}$ For a summary of the literature, see Lundberg and Pollak (1996).

${ }^{31}$ Adding a public good does not change the qualitative implications of many bargaining models, as long as spouses have heterogeneous preferences over their consumption or production (Lundberg and Pollak 1996).

${ }^{32}$ Lundberg and Pollak (1993) proposed that threat points arise from the non-cooperative equilibrium within marriage. Like ours, most tests of income pooling involve income controlled by spouses whether they are married or divorced, so it is not possible to distinguish this from the divorce threat model.
} 
spouses will claim at the ages that maximize the household surplus (which might not be the ages that maximize the present value of expected household benefits). Any effect of caddishness or decision-making power would be seen only in the division of the surplus.

A second alternative to the "common preferences" model, the "non-cooperative" separate spheres model proposed by Lundberg and Pollak (1993), assumes that the alternative to cooperative bargaining is an inefficient non-cooperating equilibrium within marriage. In this model, the allocation of income within a marriage could be costly to reverse due to high negotiation, monitoring, and enforcement costs. Where such costs are substantial in relation to the potential gain from a reallocation, a non-cooperative equilibrium based on social norms and the initial allocation will largely control the outcome.

In terms of our study, the gain in the present value of expected household Social Security benefits resulting from later claim ages are small. The costs of negotiating a "cooperative bargaining” outcome are also rather high. The parties must first of all understand the issues involved. The inter-temporal nature of any bargain poses negotiation and enforcement difficulties. Social norms might deny the wife permission to intrude in her husband's claiming decision or restrict her ability to influence that decision by making side payments. Given the bargaining problems involved in negotiating claiming ages that maximize and distribute the household surplus, a "non-cooperative" equilibrium based on social norms could well explain why so many men claim early. Caddishness and decision-making power, however, would have at best a minor effect. 
Figure 1. Social Security EPVB at Ages 63-70 as a Percentage of Age 62 EPVB - Single Men and Women

$E P V B$ at $62=100 \%$

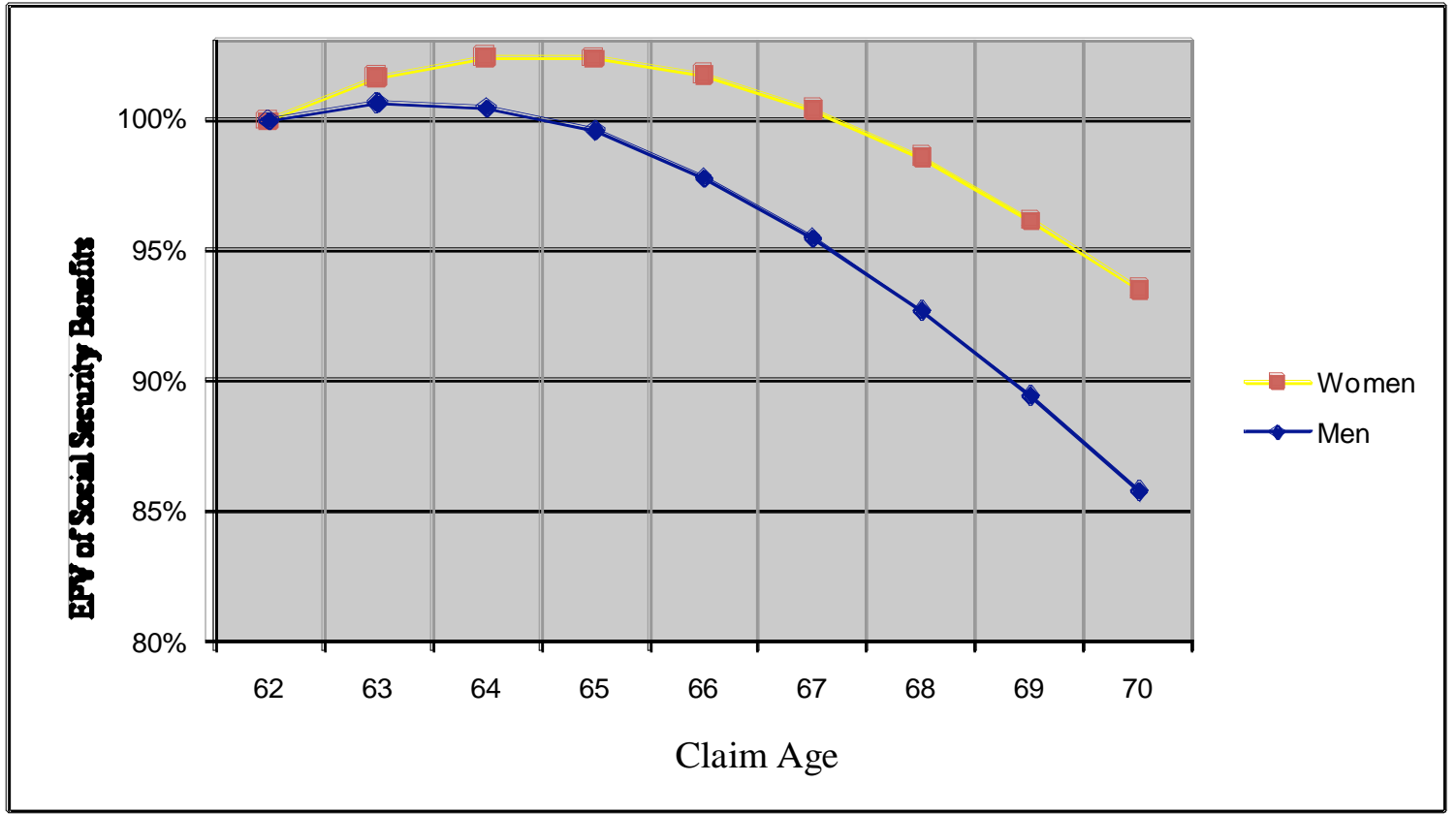

Note: Calculations assume 1937 birth cohort mortality and Social Security early retirement reduction and delayed retirement credit applicable to that cohort. 
Figure 2. Percent of Husbands Who Claimed by a Specific Age

a. 340-Observation Sample

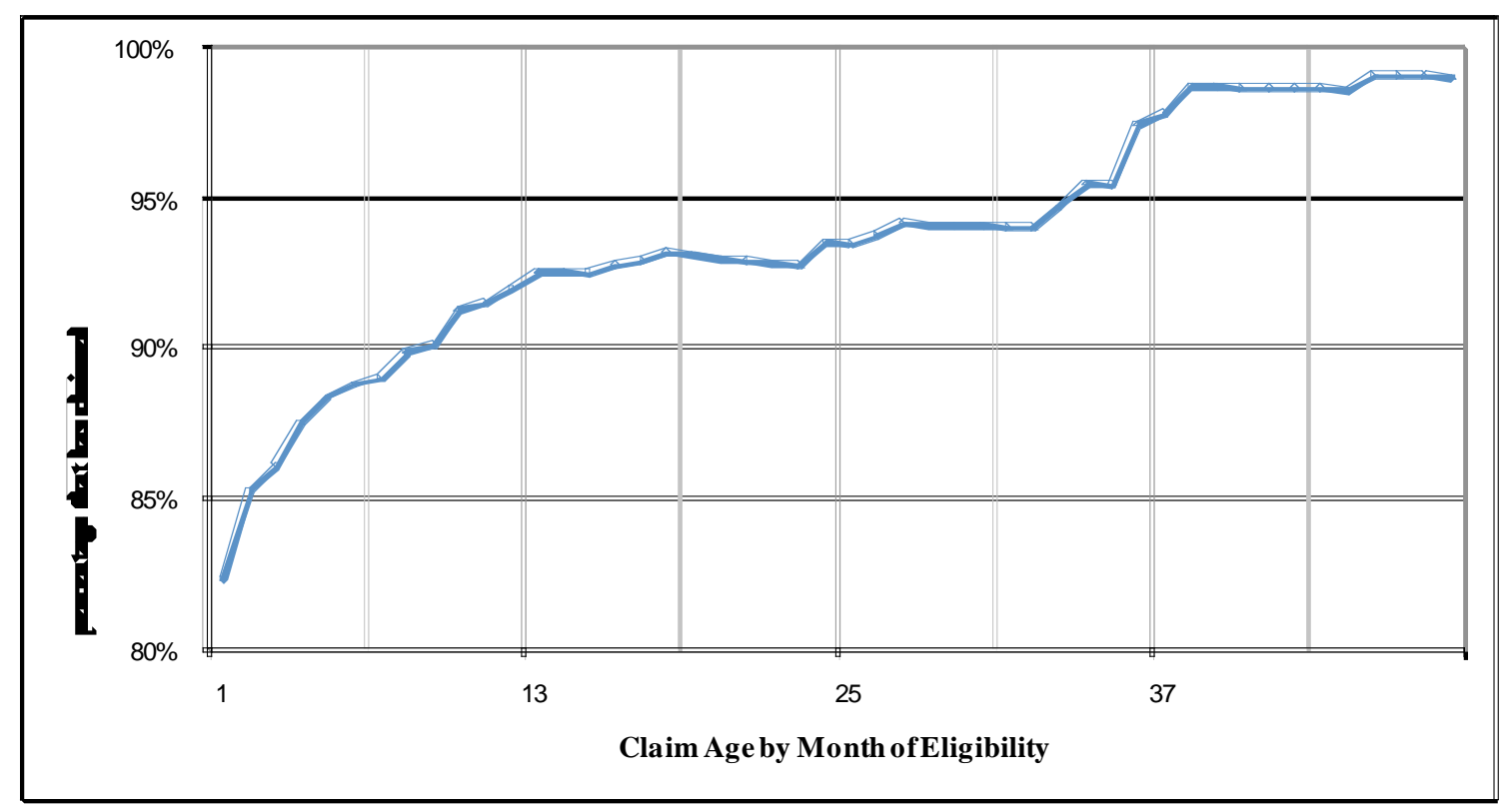

b. 187-Observation Sample

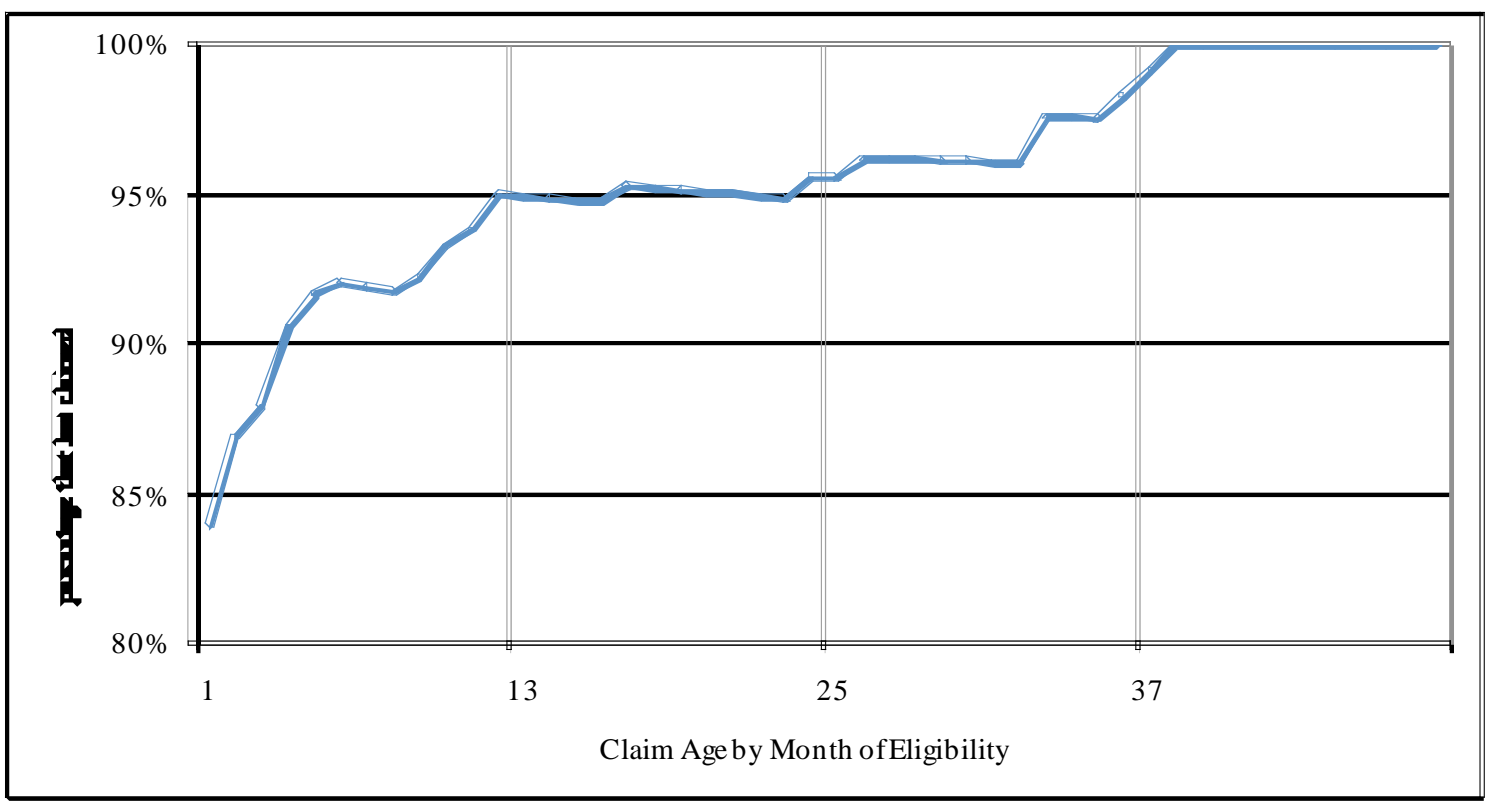


Figure 3. Mean Social Security EPVB at All Possible Claim-Age Combinations $\$, 000$ s

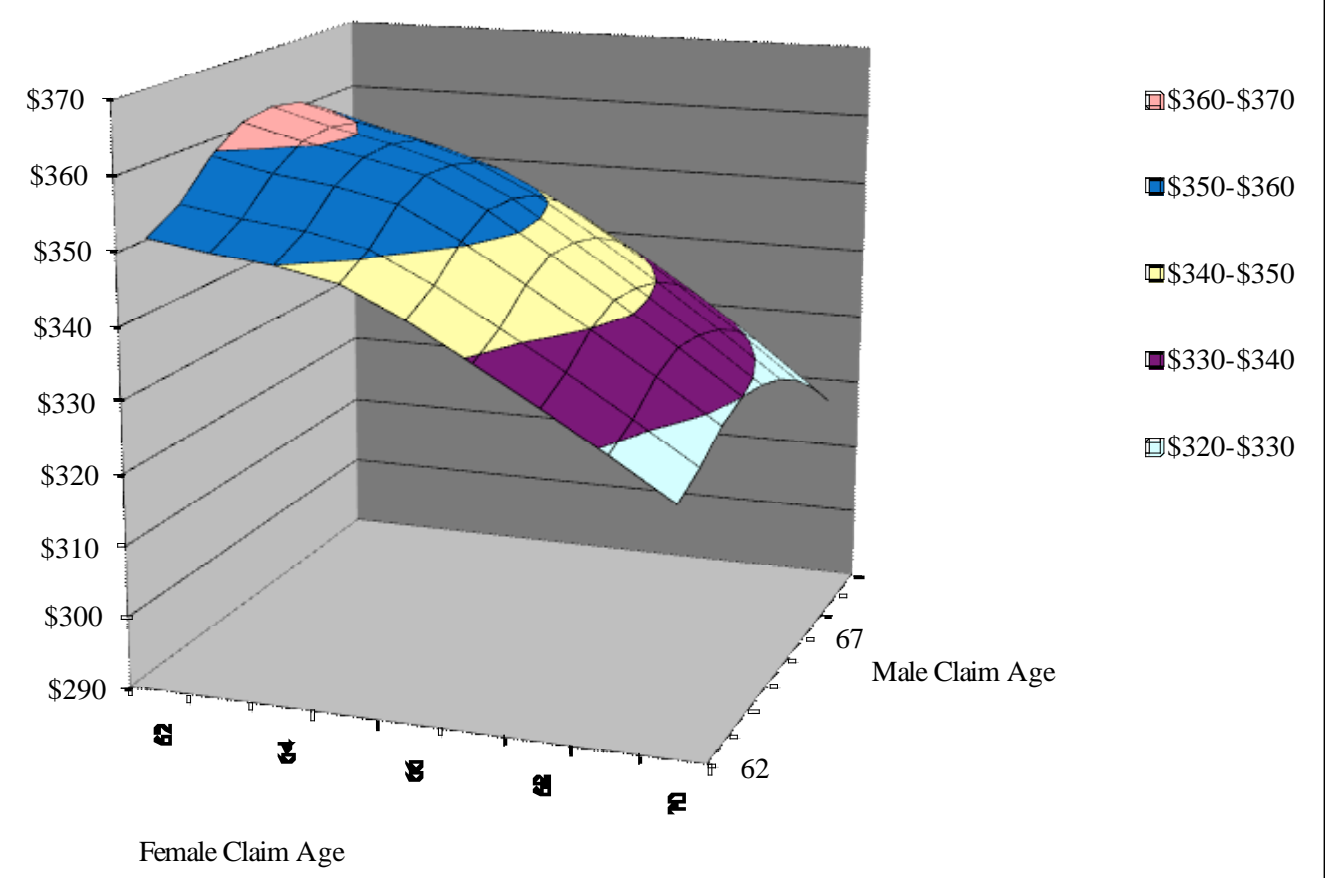

Note: Calculations assume a $3 \%$ rate of interest and assume population mortality, based on each individual's birth year; 187-observation sample.

The average annual wage-indexed lifetime earnings of households in our sample, was \$37,260 in 2007 dollars (AIME of \$3,105). 
Figure 4. Combination of Claim-Ages that Maximize Sample Household Social Security EPVB

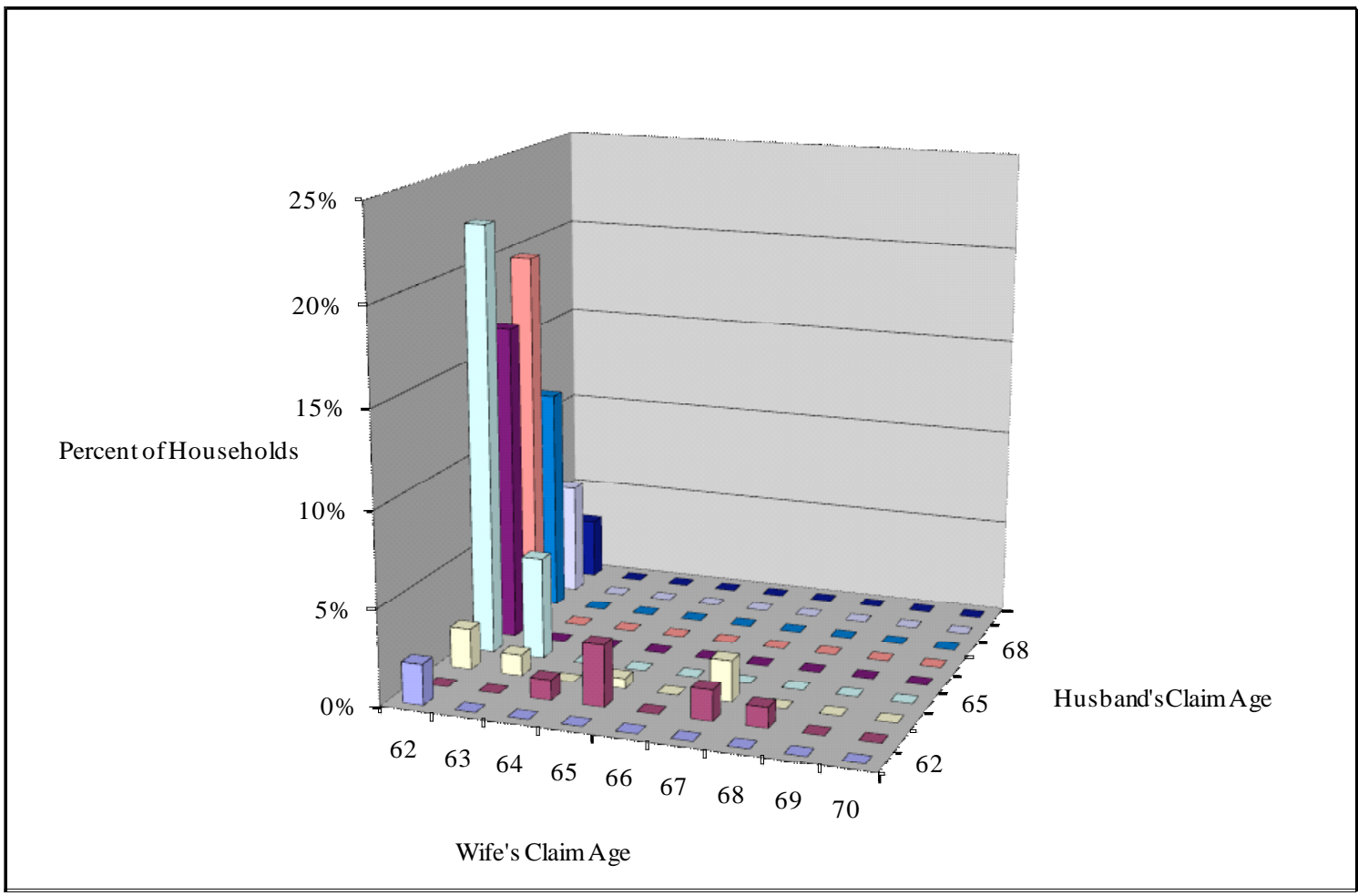

Notes: See Figure Three. 
Figure 5. Actual Husband Claim-Ages and Claim-Ages that Maximize Household Social Security EPVB.

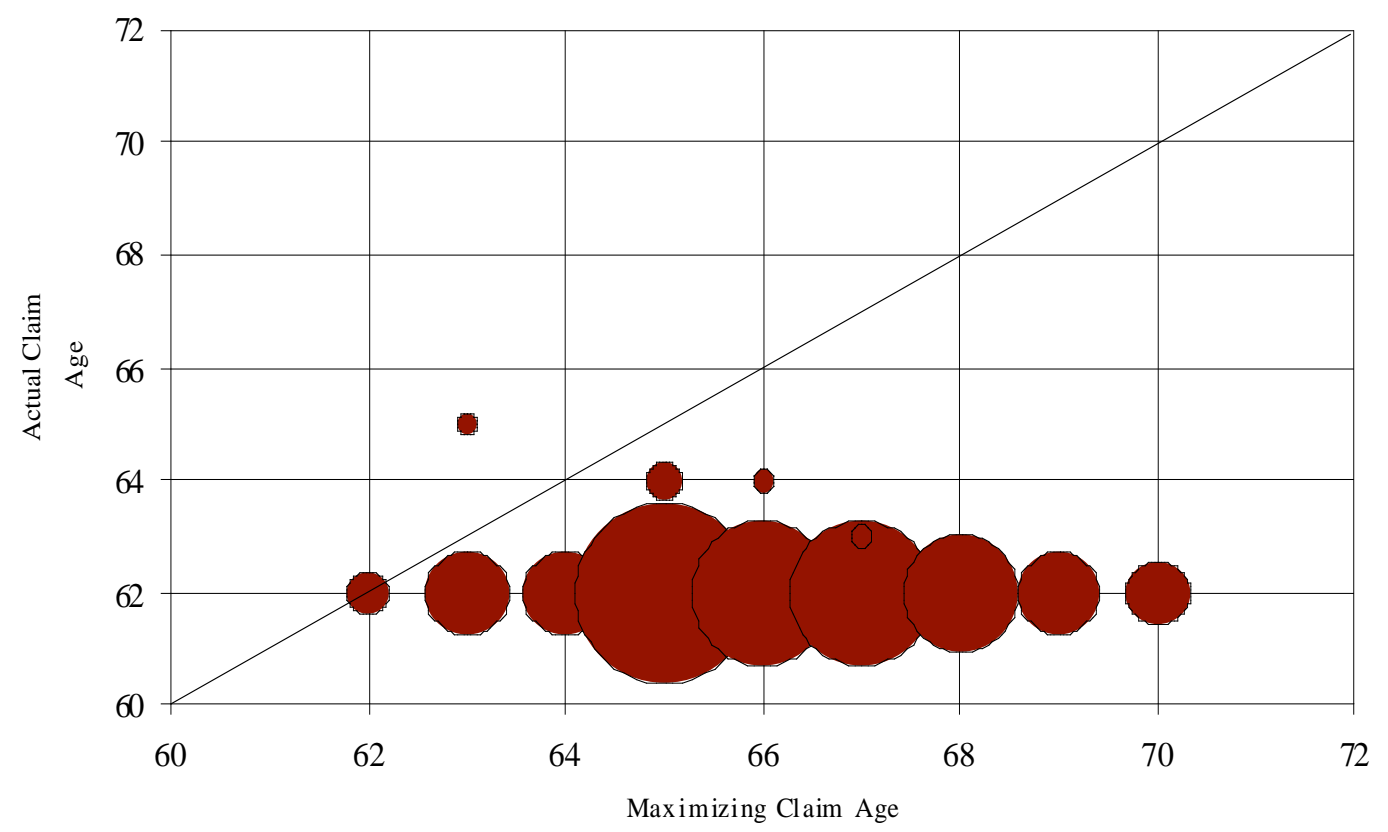

Notes: See Figure Three. 
Figure 6. Loss of Household EPVB* if the Husband and Wife Claim as Soon as Possible

a. Cumulative distribution of losses - dollars

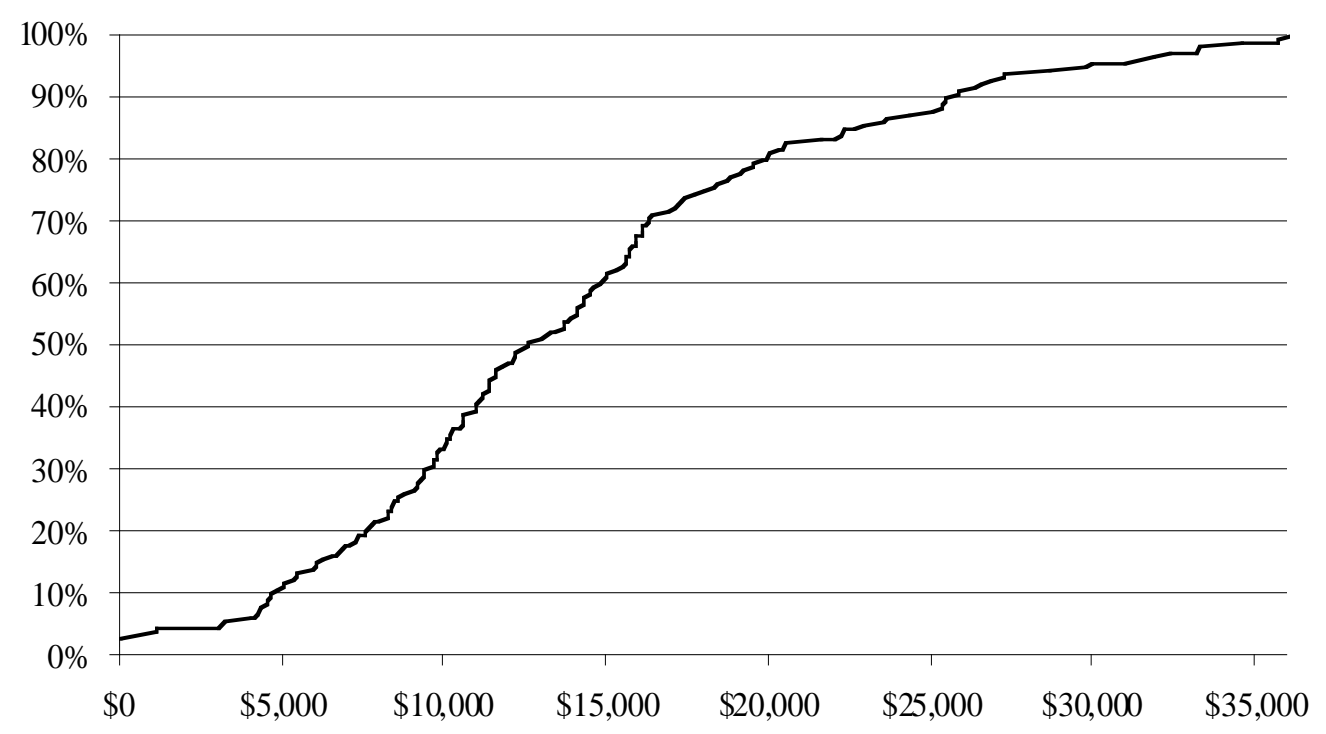

b. Cumulative distribution of losses - percentage of maximum EPVB

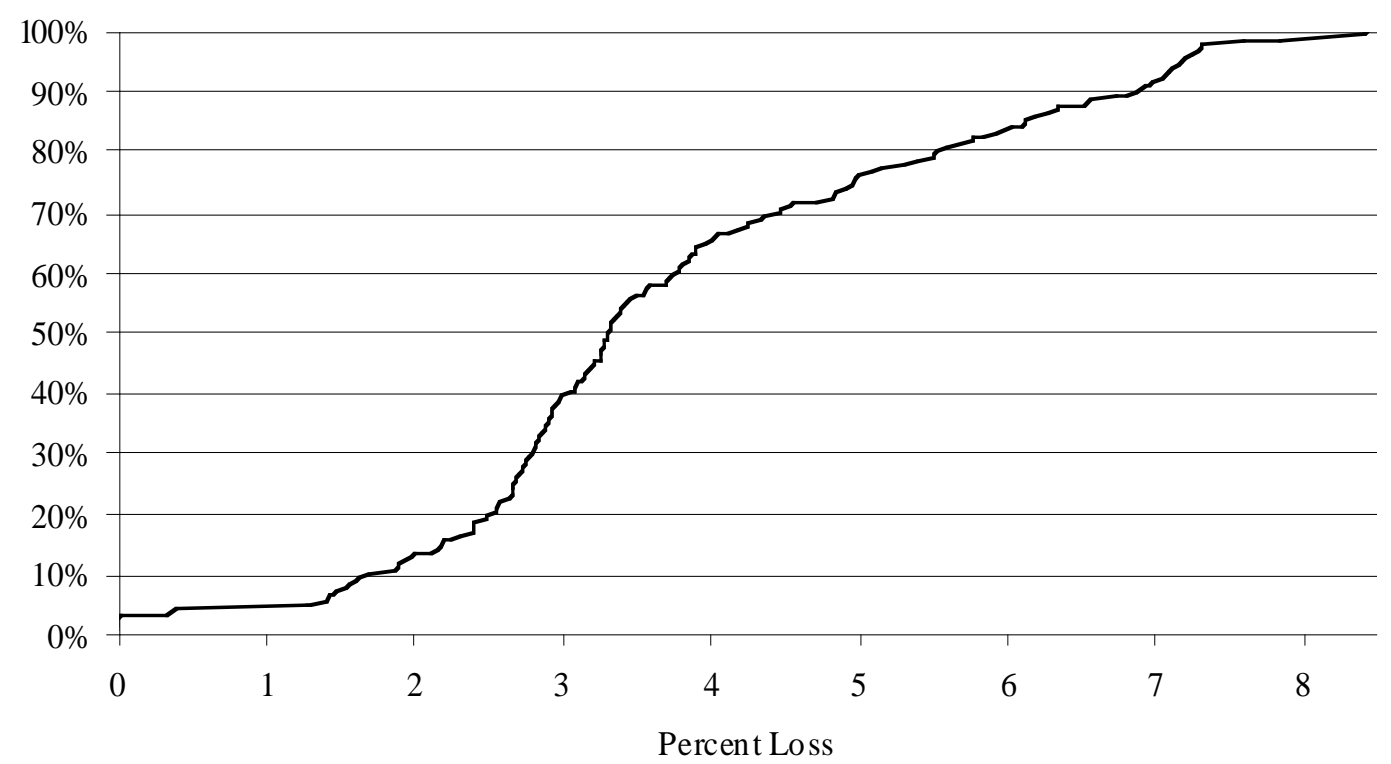

* Maximum household EPVB Less household EPVB if the husband and wife claim as soon as possible. 187-observation sample. 
Figure 7. Loss of Survivor EPVB* if the Husband and Wife Claim as Soon as Possible

a. Cumulative distribution of losses - dollars

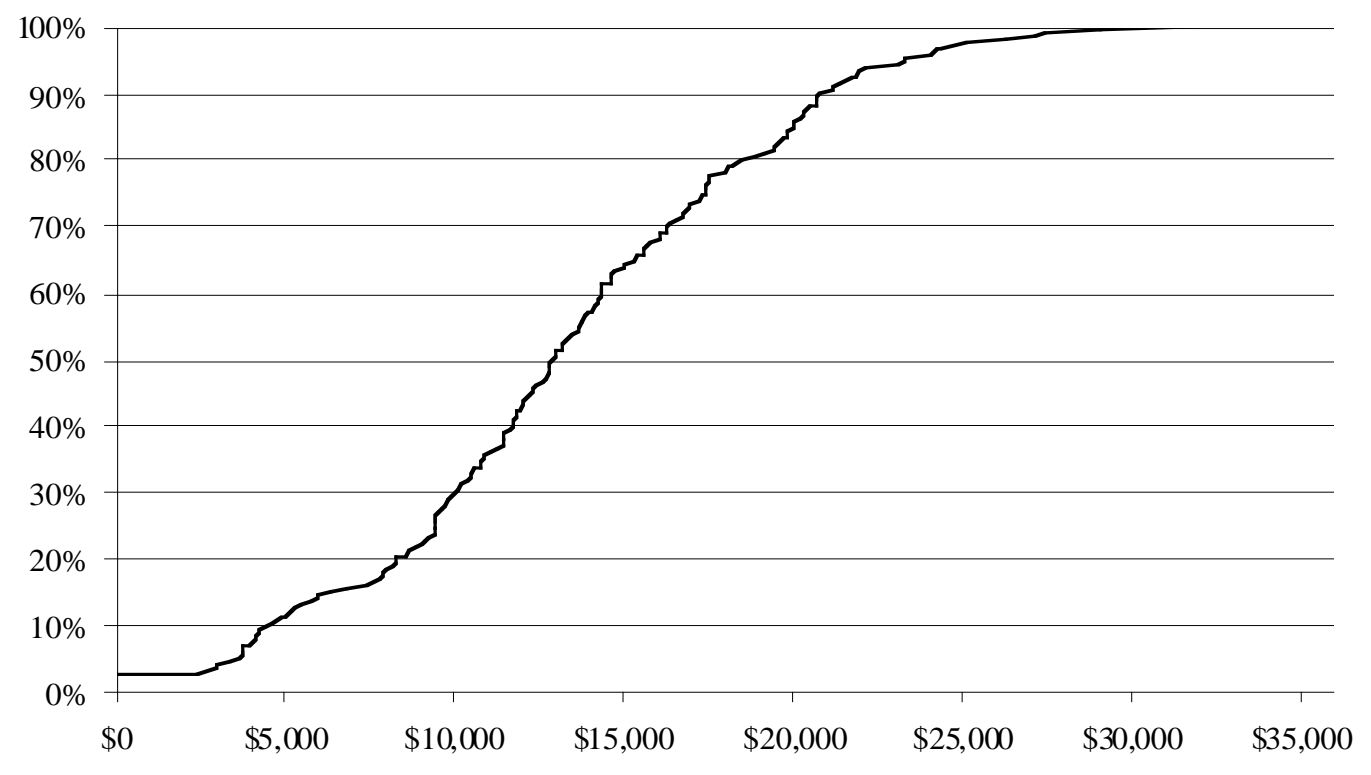

a. Cumulative distribution of losses - percentage of maximum EPVB

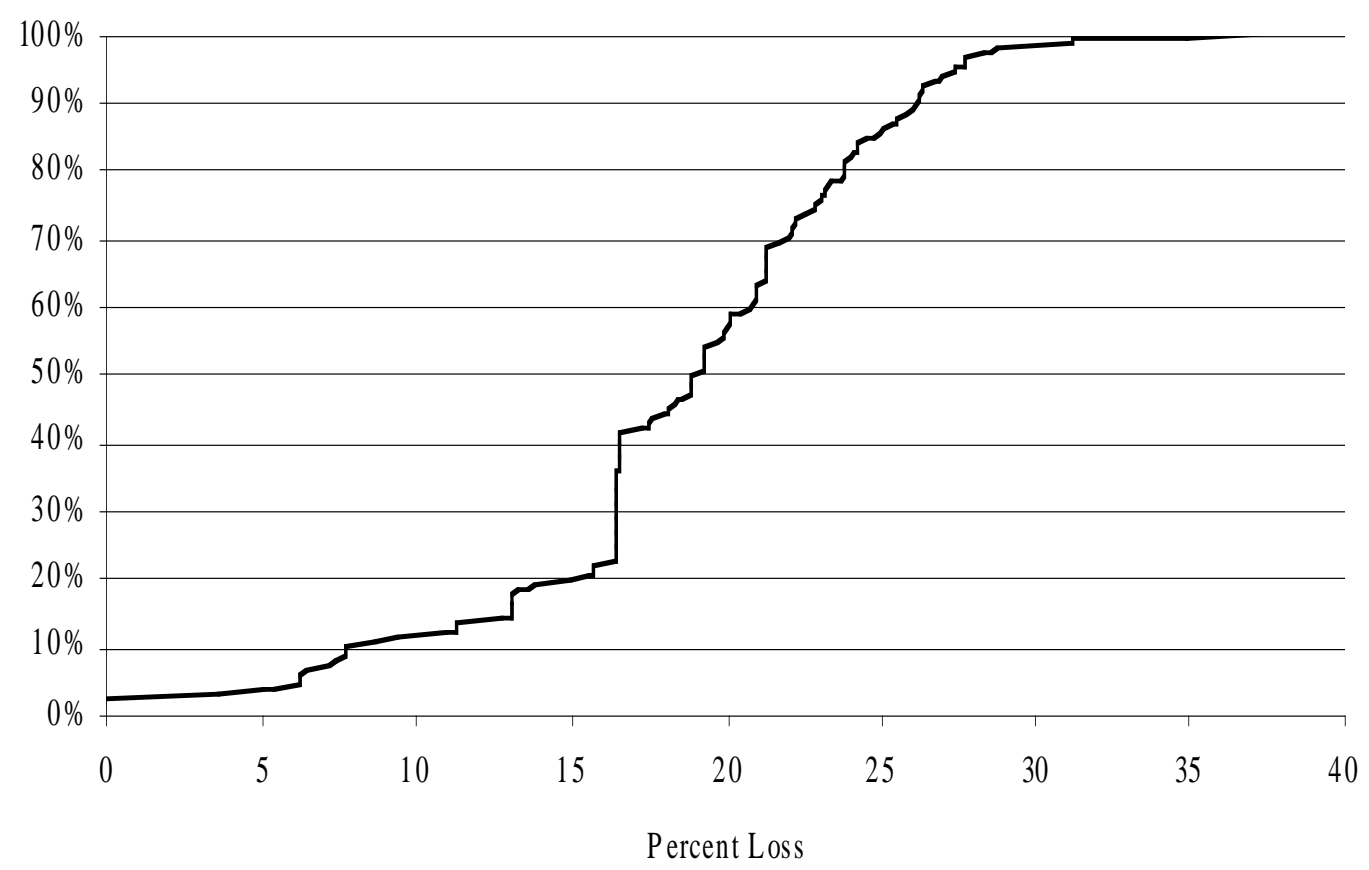

* Survivor EPVB at the household's maximizing ages less survivor EPVB if the husband and wife claim as soon as possible. 187-observation sample. 
Figure 8. Cumulative Distribution of Survivor Benefit at Actual Claim Ages and at Claim Ages that Maximize Household Social Security EPVB

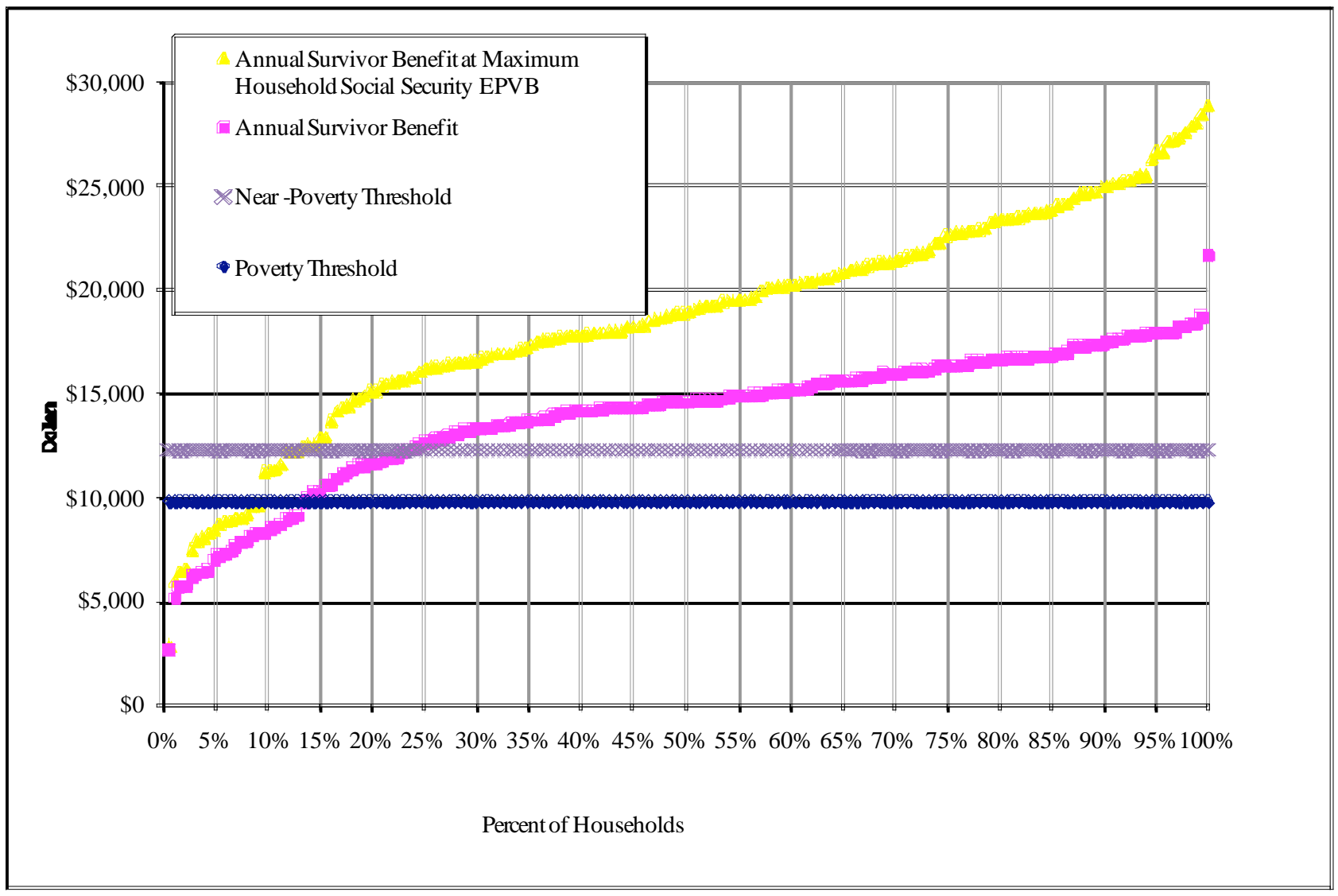

Note: Assumes that the wife claims the survivor benefit after attaining the FRA. 187-observation sample. 
Figure 9. Allocation of Social Security Wealth Based on Claim Ages

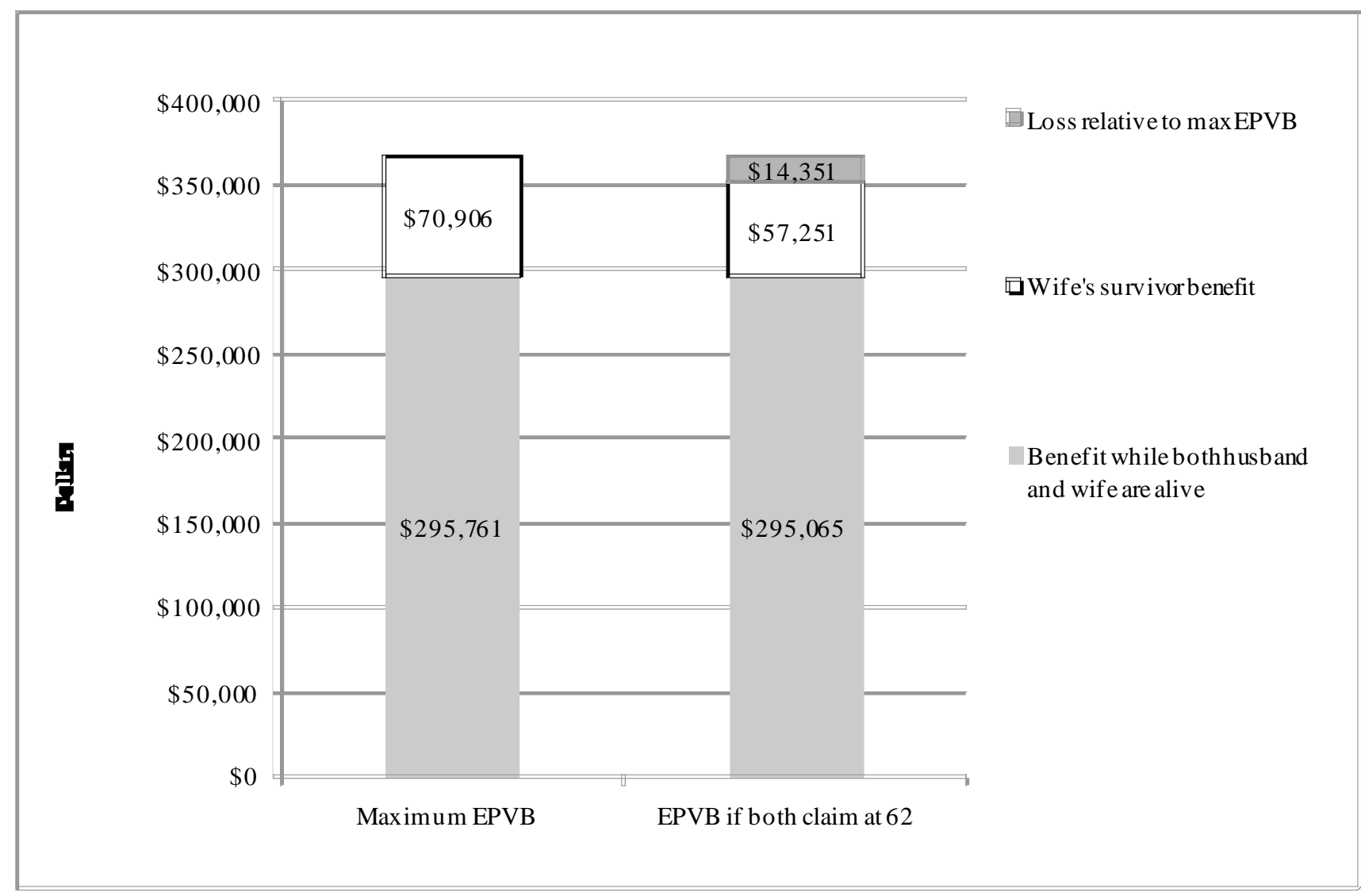

Note: 187-observation sample. 
Figure 11. Claim Ages that Maximize Household Social Security EPVB at 0\% and 5\% Interest Rates.

a. 0 percent interest rate.

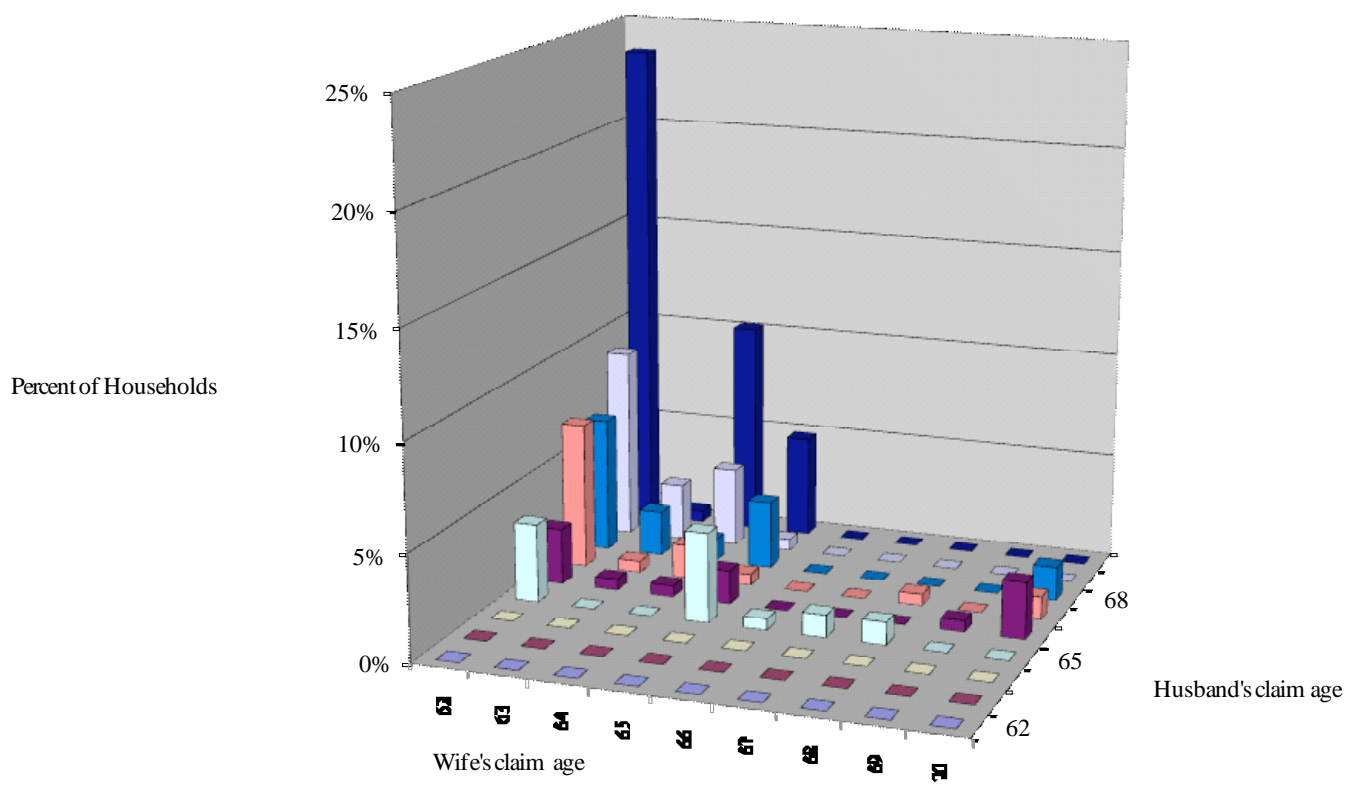

b. 5 percent interest rate.

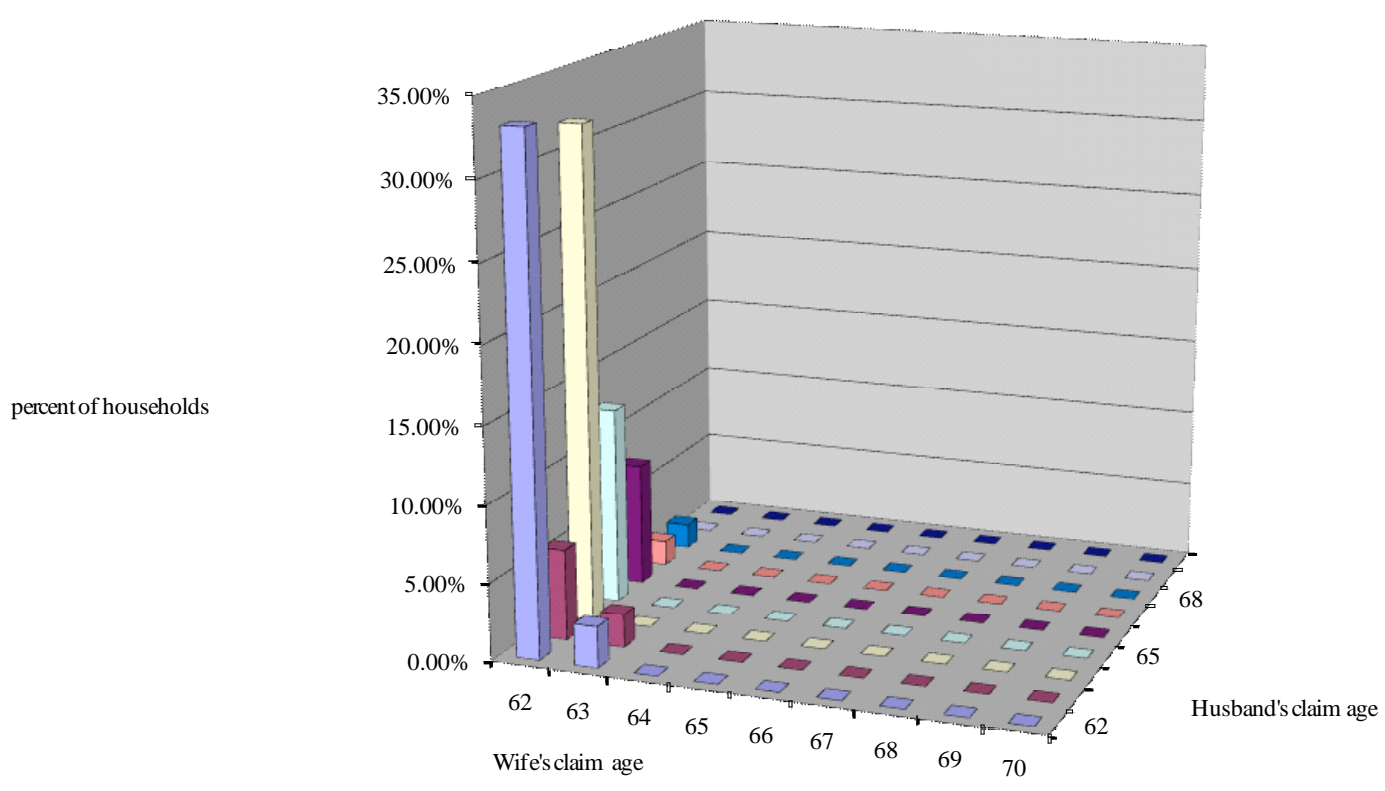

Note: 187-observation sample. 
Table 1. Construction of the sample

Married men in the HRS with linked Social Security records born between 1930 and 1941

less 5 Who married different wives between age 62 and their claim ages

less 151 Who had claimed disability benefits

less 116 Who had at least 5 consecutive years of non-FICA income

less 23 Who had not worked 40 quarters by age 62

less 30 Who had very low earnings and can be considered to never have worked

less 729 Who retired after age 62

less 2 Who lack wealth data at age 62

less 153 Whose wives lack linked earnings data 
Table 2. Characteristics of Early and Late Claimers.

\begin{tabular}{|l|c|c|c|}
\hline & Claimed at 62 & Postponed at least 1 year & Probit p value \\
\hline Non-housing financial wealth (\$,000s) & $\$ 115$ & $\$ 150$ & $\mathrm{X}$ \\
\hline Self-reported probability of living to 75 & $66 \%$ & $73 \%$ & $\mathrm{X}$ \\
\hline Planning Horizon $<1$ year & $17 \%$ & $17 \%$ & $\mathrm{X}$ \\
\hline Financially Aware & $51 \%$ & $56 \%$ & $\mathrm{X}$ \\
\hline College Education & $27 \%$ & $54 \%$ & Significant \\
\hline Husband Prefers to Spend Time Alone (Cads) & $8 \%$ & $13 \%$ & $\mathrm{X}$ \\
\hline Husband Empowered to Make Key Decisions & $28 \%$ & $38 \%$ & $\mathrm{X}$ \\
\hline Empowered Cads & $4 \%$ & $4 \%$ & $\mathrm{X}$ \\
\hline $\mathrm{N}$ & 316 & 24 & \\
\hline
\end{tabular}

340-observation sample. 
Table 3. Factors Affecting Probability a Husband Delays Claiming at Least One Year

Coeficient Std. Err. 95\% Conf.

\begin{tabular}{|l|rrr|}
\cline { 1 - 1 } Non-housing financial wealth $(\$, 000 s)$ & 0.0002289 & 0.0006445 & -0.0014921 \\
\cline { 1 - 1 } Self-reported probability of living to 75 & 0.0117127 & 0.00628 & -0.0005959 \\
\cline { 1 - 1 } Planning Horizon $<1$ year & 0.1243368 & 0.358182 & -0.577687 \\
\cline { 1 - 1 } Financially Aware & $\mathbf{0 . 0 0 8 0 7 6 9}$ & $\mathbf{0 . 2 6 0 9 1 7 7}$ & $\mathbf{- 0 . 5 0 3 3 1 2 5}$ \\
\cline { 1 - 1 } Husband Prefers to Spend Time Alone (Cads) & 0.0817067 & 0.4092067 & -0.7203237 \\
\cline { 1 - 1 } Husband Empowered to Make Key Decisions & 0.3732975 & 0.2739658 & -0.1636655 \\
Constant & -2.330416 & 0.5346845 & -3.378378
\end{tabular}


Table 4. Factors Affecting Probability a Husband Delays Claiming at Least One Year Coef. Std. Err. 95\% Conf.

\begin{tabular}{|l|}
\hline Non-housing financial wealth $(\$, 000$ s) \\
\hline Self-reported probability of living to 75 \\
\hline Planning Horizon $<1$ year \\
\hline College Educated \\
\hline Husband Prefers to Spend Time Alone (Cads) \\
\hline Husband Empowered to Make Key Decisions \\
\hline
\end{tabular}

Constant

$\begin{array}{rrr}0.0001533 & 0.0004355 & -0.0007002 \\ 0.0079674 & 0.0051223 & -0.0020721 \\ -0.0087045 & 0.303617 & -0.6037828 \\ \mathbf{0 . 5 5 1 4 3 7 8} & \mathbf{0 . 2 3 0 2 0 2 1} & \mathbf{0 . 1 0 0 2 5 0 1} \\ 0.0290723 & 0.3498108 & -0.6565443 \\ 0.2970213 & 0.238851 & -0.1711181 \\ -2.286668 & 0.4267303 & -3.123044\end{array}$




\section{References}

Brown, Jeffrey R. and James Poterba 2000. "Joint Life Annuities and Annuity Demand by Married Couples.” Journal of Risk and Insurance, 67(4): 527-53.

Coile, Courtney, Peter Diamond, Jonathan Gruber, and Alain Jousten. 2001. "Delays in Claiming Social Security Benefits,” Journal of Public Economics 84 pp 357-385

Cutler, David, Jeffrey Liebman, and Seamus Smyth. 2007. How Fast Should the Social Security Early Eligibility Age Rise?

Friedberg, Leora and Anthony Webb. 2006. Determinants and Consequences of Bargaining Power in Households National Bureau of Economic Research Working Paper No. 12367

Gruber, Jonathan, and Peter Orszag. 1999. "What To Do About the Social Security Earnings Test” Center for Retirement Research at Boston College Issue Brief No. 1

Gustman, Alan L. and Thomas L. Steinmeier. 2002. “The Social Security Early Entitlement Age in a Structural Model of Retirement and Wealth" National Bureau of Economic Research Working Paper No. 9183

Holden, Karen C. and Sean Nicholson. 1998. Selection of a Joint and Survivor Pension Institute for Research on Poverty Working Paper No. 1175-98

Hurd, Michael, D., James P. Smith, and Julie M. Zissimopoulos. 2004. "The Effects of Subjective Survival on Retirement and Social Security Claiming” Journal of Applied Econometrics 19 pp 761-775

Lundberg, Shelly, and Robert A. Pollak. 1993. "Separate Spheres Bargaining and the Marriage Market” Journal of Political Economy, December 101:6 pp988-1010

Lusardi, Annamaria. 2005. "Savings and the Effectiveness of Financial Education," inedited by Olivia Mitchell and Stephen Utkus, eds., Pension Design and Structure: New Lessons from Behavioral Finance Oxford University Press.

Lusardi, Annamaria and Olivia S. Mitchell. 2006. "Financial Literacy and Planning: Implications for Retirement Wellbeing” Pension Research Council Working Paper 2006-01

Mahaney, James and Peter Carlson. 2006. Innovative Strategies to Help Maximize Social Security Benefits. Prudential Financial. Iselin, NJ.

Manser, Marilyn, and Murray Brown. 1980. "Marriage and Household Decision Making: A Bargaining Analysis.” International Economic Review 21: 31-44.

McElroy, Marjorie and Mary Horney. 1981. "Nash-Bargained Decisions: Toward a 
Generalization of the Theory of Demand.” International Economic Review 22 (2): 333349.

McGarry, Kathleen and Robert F. Schoeni. 2005. "Widow(er) Poverty and Out-of-Pocket Medical Expenditures Near the End of Life,” The Journals of Gerontology Series B:

Psychological Sciences and Social Sciences 60 pp. S160-S168.

Mitchell, Olivia, James Poterba, Mark J. Warshawsky and Jeffrey J. Brown. 1999. "New Evidence on the Money's Worth of Individual Annuities” American Economic

Review, Vol. 89 No. 5.

Munnell, Alicia H. and Mauricio Soto. 2005. "Why Do Women Claim Social Security Benefits So Early?” Center for Retirement Research at Boston College Issue Brief No. 35 .

Saku, Aura. 2001. Does the Balance of Power Within a Family Matter: The Case of the Retirement Equity Act IGIER Working Paper 202 Milan Italy Innocenzo Gasparini Research Institute

Samuelson, Paul A. 1956. "Social Indifference Curves” Quarterly Journal of Economics Vol. 70 pp 1-22

Warner, John T. and Saul Pleeter. 2001. "The Personal Discount Rate, Evidence from Military Downsizing Programs,” American Economic Review, 91(1) pp. 33-53

Zick, Cathleen D. and Karen Holden. 2000. "An Assessment of the Wealth Holdings of Recent Widows.” Journal of Gerontology: Social Sciences 55B(2): S90-S97. 


\section{RECENT WORKING PAPERS FROM THE}

\section{CENTER FOR RETIREMENT RESEARCH AT BOSTON COLLEGE}

\section{Measurement Error in Earnings Data in the Health and Retirement Study}

Jesse Bricker and Gary V. Engelhardt, October 2007

Evaluating the Advanced Life Deferred Annuity - An Annuity People Might Actually Buy

Guan Gong and Anthony Webb, September 2007

Population Aging, Labor Demand, and the Structure of Wages

Margarita Sapozhnikov and Robert K. Triest, September 2007

Work at Older Ages: Is Raising the Early Retirement Age an Option for Social Security Reform?

John A. Turner, August 2007

The Labor Supply of Older Americans

Alicia H. Munnell and Steven A. Sass, May 2007

Why Do Japanese Workers Remain in the Labor Force So Long?

John B. Williamson and Masa Higo, May 2007

Literacy, Trust and the 401(k) Savings Behavior

Julie R. Agnew, Lisa Szykman, Stephen P. Utkus, and Jean A. Young, May 2007

The Recent Evolution of Pension Funds in the Netherlands: the Trend to Hybrid DB-DC Plans and Beyond

Eduard H.M. Ponds and Bart van Riel, May 2007

Demographic Influences on Saving-Investment Balances in Developing and Developed Economies

Ralph C. Bryant, May 2007

Social Security Spouse and Survivor Benefits for the Modern Family Melissa M. Favreault and C. Eugene Steuerle, February 2007

How Economic Security Changes During Retirement

Barbara Butrica, February 2007 